\title{
Do Food Image and Food Neophobia Affect Tourist Intention to Visit a Destination? The Case of Australia
}

\author{
Mun Yee Lai', Ying Wang', and Catheryn Khoo-Lattimore'
}

\begin{abstract}
This study examines the predictive power of cognitive and affective food image components on potential tourists' behavioral intention. Using Chinese tourists' perception of Australia as the context, the study adopted a multi-method approach incorporating desktop research, surveys of food tourism stakeholders, and quantitative testing of a model using survey data. Results confirmed that ( 1 ) cognitive food image is a formative construct, (2) cognitive food image is a stronger predictor of intention than affective image, and (3) the moderating effect of food neophobia highlights the need for a destination imagebuilding strategy to be sensitive to tourists' food-related personality traits. Study findings validate a structural model that integrates theories regarding food image and food neophobia to explain destination food image formation. Results also offer a comprehensive formative measurement model of cognitive food image for future research.
\end{abstract}

\section{Keywords}

destination food image, food tourism, food neophobia, potential Chinese tourist, formative image construct

\section{Introduction}

Food is a key factor in tourists' holiday decision making: a recent survey found that $64 \%$ of tourists chose their next destination based on the options and appeal of local cuisines, foods, and beverages (Travel Weekly 2018). Therefore, understanding how people form their opinion and image of food destinations before making the actual visit is crucial to identifying image attributes that have the most significant impact on impressions of the place (Tasci, Gartner, and Tamer 2007; Kim et al. 2012).

Destination image (DI) is a perception of a destination as reflected in the quality of its tourism offerings (e.g., attractions, shopping and dining facilities, entertainment, and accommodation). Tourists usually arrange associations with the image and their symbolic and experiential values in some meaningful way and hold these associations in their memories (Aaker 1991; Keller 1993; Cai 2002).

Importantly, current modeling of antecedents of DI is built on the notion that image embraces both perception and emotional evaluations (Hunt 1971; Gunn 1972; Keller 1993). As a result, DI is measured as a multidimensional construct formed by cognitive and affective images of a destination's attributes (Baloglu and McCleary 1999) that affect tourists' behavioral intention and destination choice (Gallarza, Saura, and García 2002).

Despite theoretical knowledge on the formation of DI, research has often taken a piecemeal approach to interpreting the food dimensions that represent a place, with the result that empirical studies on destination food image are few. In particular, indicators used for measuring food images vary considerably between studies in terms of the weight and meaning given to the dimensions of the examined food image, and in recent years, researchers have called for development of a comprehensive destination food image model (Seo and Yun 2015; Lin, Pearson, and Cai 2011).

Scholars have emphasized the need to create a measurement for cognitive food image and to determine its key dimensions (Lai, Khoo-Lattimore, and Wang 2017; Lin, Pearson, and Cai 2011; Williams, Williams, and Omar 2014), especially as consensus is lacking as to cognitive food image measurement between tourist and host studies and across different destinations (Sanchez-Cañizares and Castillo-Canalejo 2015; Seo and Yun 2015). Arguably, existing measures do not adequately capture what a destination has to offer,

\footnotetext{
'Griffith Business School, Department of Tourism, Sport \& Hotel Management, Griffith University, Nathan Campus, Queensland, Australia ${ }^{2}$ Griffith Business School, Department of Tourism, Sport \& Hotel Management, Griffith University, Gold Coast Campus, Queensland, Australia

\section{Corresponding Author:}

Mun Yee Lai, PhD Graduate, Griffith Business School, Department of Tourism, Sport \& Hotel Management, Griffith University, Nathan Campus, Queensland 4III, Australia.

Email: munyee.lai@griffithuni.edu.au
} 
hindering theory development owing to the incomparability of findings on cognitive food image across studies.

In an attempt to develop a more comprehensive food image model, this research investigates the reflective versus formative nature of the destination image construct. Conventionally, cognitive image has been conceptualized as a reflective construct, which assumes that indicators of the construct are interchangeable and correlated and that the direction of causality is from the construct to the indicators (Diamantopoulos, Riefler, and Roth 2008; Fornell and Bookstein 1982; Hair et al. 2017). In contrast, a formative construct denotes a construct that is caused by its indicators. Scholars have increasingly argued for cognitive image to be considered a formative construct given that tourists' beliefs and attitudes regarding a variety of destination attributes collectively form their image, and their views of different destination attributes are not necessarily correlated (Diamantopoulos, Riefler, and Roth 2008; do Valle and Assaker 2016; Kock, Josiassen, and Assaf 2016). For instance, a tourist may have a positive perception of tourism attractions but be highly critical of service quality. This study is the first to provide empirical evidence to clarify the formative versus reflective nature of a destination image construct.

Another gap in the food image literature lies in the incorporation of tourists' feelings toward a food destination as emotional responses, which are required to understand and predict the behavior of tourists but which have not been established (Seo and Yun 2015; Stone et al. 2017). Finally, food image research can benefit greatly from exploration of the influence (or moderating role) of tourists' food-related personality traits on perceived food image prior to their decision to visit a food destination (Wu et al. 2016). While some studies have investigated the role of personality traits, the focus has been on tourists' actual consumption of local food during a trip, such as tourists' attitudes toward novel food and their acceptance of foods based on actual dining experiences (Chang, Kivela, and Mak 2010), rather than on understanding the influence of these personality traits in the process of previsit image formation.

In response to these calls, and building on prior literature and qualitative insights, this study proposes a conceptual model of destination food image. The model was empirically tested using data collected through an online survey of potential Chinese tourists to Australia with regard to their perceptions of and attitudes toward Australia as a food tourism destination. The study aimed at uncovering tourists' perceptions about Australia as a food destination, which might in turn influence their intention to visit. Exploring perceptions can reveal ideas and beliefs regarding food that tourists hold as a result of their awareness of a destination. When perception becomes more ingrained, it forms an attitude that influences behavior - that is, the attitude is a result of the perception and evaluation of qualities associated with destination tourism offerings (Aaker 1991; Keller 1993).
The study's objectives were (1) to test a formative measure of cognitive food image and identify the key attributes and dimensions of food tourism in Chinese tourist perceptions; (2) to test a full model derived from destination image formation literature that predicts intentions to visit a food destination, and (3) to examine the role of food-related personality traits-including food neophobia and novelty seeking - in shaping the relationships between key constructs in the model. Theoretically, this work aims to enrich the body of knowledge of destination food image by examining the multidimensional nature of the food image concept through both cognitive and affective evaluation, and also by investigating the relationship between tourists' personality trait of food neophobia and the perceived image of destination food offerings.

Chinese tourism to Australia was chosen for study because of China's growing significance as a market both for Australia and globally. Worldwide, China has become the largest tourism market and biggest tourism spender, spending US\$261 billion in 2016, twice the amount spent by other international tourists (World Tourism Organization 2017). China has also been the largest market in terms of spending in Australia, contributing AU\$10.4 billion in 2017 (Tourism Australia 2018).

However, previous research has identified a gap between Chinese tourists' perceived image of Australia as a food destination and their actual experience (Tourism Australia 2014). Little is known about the causes of this perceptual gap, and to enhance competitiveness and effectively capitalize on the growth of the Chinese market, Western-oriented destinations need to adopt a more culturally sensitive approach to market destination for Chinese tourists (Becken and Scott 2016; Chang, Kivela, and Mak 2011; Wang and Davidson 2010). Practically, this study provides a timely guide to marketing and promotional strategies' prioritizing of image improvement efforts based on the aspects most important to prospective Chinese tourists.

\section{Literature Review}

\section{Destination Image}

The literature on destination image (DI) emphasizes that image research seeks to audit perceptions formed in the minds of tourists and identify specific image attributes that have the most significant impact on the impressions of a place (Tasci, Gartner, and Tamer 2007). Owing to its impact on both supply and demand aspects of marketing, the concept of DI has long been gauged as critical to tourism development and destination marketing success (Tasci and Gartner 2007). To the destination host, image is a key construct in destination positioning and promotion (Pike and Ryan 2004) and employment of tourism resources (Sun, Ryan, and Pan 2015) and is recognized as an expression of 
identity and personality (Ekinci and Hosany 2006). To the tourist, image is a key construct in perceived attractiveness and quality, the destination selection process, and behavioral intention (Gallarza, Saura, and García 2002; Prayag and Ryan 2012). The ultimate goal of analyzing DI is twofold: to help destinations better articulate a destination marketing strategy by developing positive images and messaging that resonate with a target tourism market, and to create alignment between marketers, local businesses, and tourists.

To conceptualize how tourists form opinions and ideas about a place, the destination image formation model comprises three hierarchically interrelated components: cognitive, affective, and conative (Gartner 1994). All three driver components are related to the attitudinal constructs consisting of (1) a cognitive image, which refers to a person's knowledge, intellect, beliefs, and perceptions about the attributes of a destination; (2) an affective image, which involves a person's feelings and emotions toward a destination; and (3) a conative image, which is a behavioral intention component reflecting how attitude influences the way a person acts or behaves (Gartner 1994; O’Shaughnessy 1992). Scholars who have employed the destination image formation model have provided empirical evidence of the positive effect of the cognitive and affective constructs of perceived DI on tourists'

conative-behavioral responses, such as tourist satisfaction and loyalty (Chen and Phou 2013; Guzman-Parra, VilaOblitas, and Maqueda-Lafuente 2016; Prayag 2009) and visit intention (Pike and Ryan 2004). Cognitive and affective images are often conceptualized as components of DI (e.g., Martín and del Bosque 2008; Molinillo et al. 2018) or, alternatively, as an image structure that emphasizes the overall image component resulting from the cognitive and affective evaluation (Baloglu and McCleary 1999; Qu, Kim, and Im 2011; Papadimitriou, Kaplanidou, and Apostolopoulou 2018).

In operationalizing DI, past studies have typically used methods such as structural equation modeling (SEM) to conceptualize DI as a reflective construct. However, in recent years marketing scholars have challenged this characterization, arguing that the construct is theoretically formative but has been mis-specified as reflective (Diamantopoulos, Riefler, and Roth 2008; Huang, Weiler, and Assaker 2015). This view has been supported by subsequent work asserting that "an individual's diverse destination associations can only be appropriately captured as a formative measure"

(Kock, Josiassen, and Assaf 2016, 35). Not surprisingly, tourists' image of a destination is a combination of perceptions of various destination dimensions that are not always interrelated, such as environment, culture, people, quality, places, and activities. Thus, formative indicators (destination image attributes) are rather collective in forming the cognitive image construct. Accordingly, this study provides evidence for a formative cognitive food image construct and details the theoretical argument and empirical evidence.

\section{Destination Food Image}

Despite the increasing attention from researchers, no consensus exists as to the determinants of food image. Studies on food image take either a host or tourist perspective and attempt to explain the complex nature of the food image as being socioculturally constructed and varying across different stakeholders, such as host versus guest (Sims 2009), and different market segments (Lertputtarak 2012; Kivela and Crotts 2006). Studies of destination food image from the host perspective have investigated food as a tourism resource (Smith and Xiao 2008) or as an identity of the destination (Lin, Pearson, and Cai 2011), as in the case of attractive food festivals (Blichfeldt and Halkier 2013; Lee and Arcodia 2011), agricultural food produce (Che 2006), or geographically specific regional food heritage (Sims 2009; Tellström, Gustafsson, and Mossberg 2006).

Tourist-image studies have investigated food as having both functional and symbolic value for tourists, encompassing a way of experiencing local food culture, regional cuisine, novel food, quality food, restaurants, and activities relating to food festivals, events, tours, and cooking classes. Table 1 provides a summary of tourist-image studies and suggests that the number of food attributes used in cognitive food image evaluation varies across studies. For instance, a comparison of local cuisines of Spain and Slovenia used seven attributes signifying the place's traditional food, quality dishes, innovative dish, price value, service, dining atmosphere, and facilities (Sanchez-Cañizares and Castillo-Canalejo 2015). In contrast, an assessment of traditional Korean cuisine used 28 attributes in five dimensions: safety/quality, food attractiveness, health benefits, food culture, and culinary art (Seo and Yun 2015).

Cognitive food image is an important construct in explaining tourists' intention to visit a destination (Kim et al. 2012) and their satisfaction with their food and travel experiences (Sanchez-Cañizares and Castillo-Canalejo 2015; Peštek and Cinjarevic 2014). In general, studies have focused predominantly on cognitive food image without considering the role of affective image (Björk and Kauppinen-Räisänen 2016; Sanchez-Cañizares and CastilloCanalejo 2015; Karim and Chi 2010), or have considered both cognitive and affective images without testing their subsequent effects on conative image (Seo and Yun 2015; Peštek and Cinjarevic 2014). Only one study tested the cognitive-affective-conative model (Peštek and Cinjarevic 2014), and the attributes examined focused heavily on cuisine and the cultural dimension without taking into account other relevant aspects, such as dining places and the food environment. Results showed a positive relationship between cognitive and affective images and satisfaction, and the researchers concluded that food image and satisfaction levels varied across different market segments and recommended measuring tourists' emotions and exploring tourists' food-related attitudes toward a destination. 
Table I. Summary of Destination Food Image Studies from the Tourists' Perspectives.

\begin{tabular}{|c|c|c|c|c|c|c|c|}
\hline \multirow[b]{2}{*}{ Author (year) } & \multirow[b]{2}{*}{ Aims } & \multirow[b]{2}{*}{ Research Instrument } & \multirow{2}{*}{$\begin{array}{l}\text { Statistical } \\
\text { Analysis }\end{array}$} & \multicolumn{3}{|c|}{$\begin{array}{c}\text { Determinants and measurement of Destination } \\
\text { Food Image (DFI) }\end{array}$} & \multirow[b]{2}{*}{ Contributions / Limitation } \\
\hline & & & & $\mathrm{CFI}$ & AFI & INT & \\
\hline $\begin{array}{l}\text { Björk and } \\
\text { Kauppinen- } \\
\text { Räisänen (2016) }\end{array}$ & $\begin{array}{l}\text { Finnish food: } \\
\text { Examined determinants of } \\
\text { local food image among } \\
\text { different types of food } \\
\text { tourists. } \\
\text { Testing: } \\
\text { Cognitive component } \\
\text { - CFI }\end{array}$ & $\begin{array}{l}\text { Survey - local/domestic } \\
\text { tourists. }(n=158)\end{array}$ & $\begin{array}{l}\text { (i) ANOVA, } \\
\text { mean score }\end{array}$ & $\begin{array}{l}\text { Cognitive } \\
\text { (17 indicators) } \\
3 \text { dimensions: } \\
- \text { food culture } \\
\text { - novel food } \\
\text { - dining places }\end{array}$ & - Not tested & - Not tested & $\begin{array}{l}\text { - Measured DFI from the local/domestic } \\
\text { tourist perspectives. } \\
\text { - CFI evaluation focused on local food and } \\
\text { restaurants. } \\
\text { - Identified } 3 \text { segments of food tourist } \\
\text { behavior based on their perceived } \\
\text { importance of food experiences. } \\
\text { Limitation: } \\
\text { - Only CFI construct is measured, and } \\
\text { limited to food culture and dining place } \\
\text { dimensions, understanding of destination } \\
\text { food image is questionable. }\end{array}$ \\
\hline $\begin{array}{l}\text { Seo and Yun } \\
(2015)\end{array}$ & $\begin{array}{l}\text { Korean food: } \\
\text { Developed and validated } \\
\text { measurement scale for } \\
\text { DFI. } \\
\text { Testing: } \\
\text { Cognitive-affective } \\
\text { components } \\
\text {-CFI and AFI }\end{array}$ & $\begin{array}{l}\text { Focus group - } \\
\text { expatriates who live } \\
\text { in Korea }(n=19) \\
\text { Survey: international } \\
\text { tourists-American, } \\
\text { Japanese, and Chinese } \\
\text { (postvisit) }(n=357)\end{array}$ & $\begin{array}{l}\text { (i) Thematic } \\
\text { analysis } \\
\text { (ii) EFA } \\
\text { (iii) CFA }\end{array}$ & $\begin{array}{l}\text { Cognitive } \\
\text { ( } 28 \text { indicators) } \\
5 \text { dimensions: } \\
\text { - safety/quality } \\
\text { - attractiveness } \\
\text { - health benefit } \\
\text { - food culture } \\
\text { - culinary arts }\end{array}$ & $\begin{array}{l}\text { Affective } \\
\text { (5 indicators) } \\
\text { - contented } \\
\text { - fulfilled } \\
\text { - pleasant } \\
\text { - enjoyable } \\
\text { - exciting }\end{array}$ & - Not tested & $\begin{array}{l}\text { - Proposed measurement model of DFI } \\
\text { - Evaluating CFI using } 5 \text { dimensions derived } \\
\text { from international participants. } \\
\text { - Integrated AFI evaluation in the model. } \\
\text { - Identified nationality as a construct } \\
\text { influencing DFI. } \\
\text { Limitation: } \\
\text { - Attributes evaluating food culture } \\
\text { constructs are unique to traditional } \\
\text { Korean cuisine characteristics, possibly } \\
\text { irrelevant for other destination cuisines. } \\
\text { - The CFI dimensions were limited to } \\
\text { food culture and food quality, lack of } \\
\text { reflection of others' food tourism } \\
\text { offerings, e.g., dining places, people, food } \\
\text { activities. }\end{array}$ \\
\hline
\end{tabular}


Table I. (continued)

\begin{tabular}{|c|c|c|c|c|c|c|c|}
\hline \multirow[b]{2}{*}{ Author (year) } & \multirow[b]{2}{*}{ Aims } & \multirow[b]{2}{*}{ Research Instrument } & \multirow{2}{*}{$\begin{array}{l}\text { Statistical } \\
\text { Analysis }\end{array}$} & \multicolumn{3}{|c|}{$\begin{array}{c}\text { Determinants and measurement of Destination } \\
\text { Food Image (DFI) }\end{array}$} & \multirow[b]{2}{*}{ Contributions / Limitation } \\
\hline & & & & $\mathrm{CFI}$ & AFI & INT & \\
\hline $\begin{array}{l}\text { Sanchez-Cañizares } \\
\text { and Castillo- } \\
\text { Canalejo (20I5) }\end{array}$ & $\begin{array}{l}\text { Spanish and Slovenian } \\
\text { foods: } \\
\text { Compared the influences } \\
\text { of } 2 \text { destinations' food } \\
\text { images on tourist } \\
\text { motivation, willingness } \\
\text { to pay for local food and } \\
\text { wine, and satisfaction with } \\
\text { their visit. } \\
\text { Testing: } \\
\text { Cognitive-conative } \\
\text { components } \\
\text { Hypothesis I: } \\
\text { CFI } \rightarrow \text { SAT }\end{array}$ & $\begin{array}{l}\text { Survey: both domestic } \\
\text { and international } \\
\text { tourists who had } \\
\text { visited the destination. } \\
(n=392)\end{array}$ & $\begin{array}{l}\text { (i) ANOVA, } \\
\text { mean } \\
\text { score } \\
\text { (ii) } t \text {-test } \\
\text { (iii) multiple } \\
\text { regression }\end{array}$ & $\begin{array}{l}\text { Cognitive } \\
\text { (7 indicators) } \\
\text { - traditional food } \\
\text { - service quality } \\
\text { - dishes } \\
\text { - atmosphere } \\
\text { - facilities } \\
\text { - price } \\
\text { - innovative dish }\end{array}$ & - Not tested & $\begin{array}{l}\text { Conative } \\
\text { (2 indicators) } \\
\text { - Satisfaction with } \\
\text { gastronomy } \\
\text { experiences } \\
\text { - Willingness to } \\
\text { pay more for } \\
\text { local cuisine }\end{array}$ & $\begin{array}{l}\text { - Evaluating CFI through an economic } \\
\text { approach, comparing competitiveness and } \\
\text { strength between } 2 \text { destinations. } \\
\text { - Confirmed high correlation between CFI } \\
\text { and satisfaction. } \\
\text { - Identified well-known or recognizable } \\
\text { cuisine is the key attributes to attract } \\
\text { tourists, and local cuisine is the attribute } \\
\text { tourists valued. } \\
\text { Limitation: } \\
\text { - Few items to measure CFI, limited } \\
\text { measurement, and basic understanding } \\
\text { of food tourism offerings. } \\
\text { - Mixing both domestic and international } \\
\text { tourists in a survey makes it difficult to } \\
\text { explain the level of knowledge, familiarity, } \\
\text { and importance of local food image. } \\
\text { - Affective food image was not evaluated. }\end{array}$ \\
\hline $\begin{array}{l}\text { Peštek and } \\
\text { Cinjarevic (2014) }\end{array}$ & $\begin{array}{l}\text { Bosnian food: } \\
\text { Explored the underlying } \\
\text { dimensions of local cuisine } \\
\text { image, as perceived by } \\
\text { tourists. } \\
\text { Testing: } \\
\text { Cognitive-affective-conative } \\
\text { components } \\
\text { Hypothesis I: } \\
\text { CFI } \rightarrow \text { AFI } \rightarrow \text { OFI } \\
\text { Hypothesis 2: } \\
\text { CFI } \rightarrow \text { SAT }\end{array}$ & $\begin{array}{l}\text { Survey - international } \\
\text { tourists who visited } \\
\text { the destination and } \\
\text { tasted the local } \\
\text { cuisine }(n=402) \\
\end{array}$ & $\begin{array}{l}\text { (i) EFA } \\
\text { (ii) CFA } \\
\text { (iii) Multiple } \\
\text { regression }\end{array}$ & $\begin{array}{l}\text { Cognitive } \\
\text { (1I indicators) } \\
3 \text { dimensions: } \\
\text { - uniqueness and } \\
\text { cultural heritage } \\
\text { - quality and price } \\
\text { - nutrition and } \\
\text { health }\end{array}$ & $\begin{array}{l}\text { Affective } \\
\text { (4 indicators) } \\
\text { - exciting } \\
\text { - arousing } \\
\text { - pleasant } \\
\text { - relaxing }\end{array}$ & $\begin{array}{l}\text { Conative } \\
\text { (3 indicators) } \\
\text { - Satisfaction } \\
\text { with food } \\
\text { experiences } \\
\text { - Perceived } \\
\text { value and } \\
\text { expectations } \\
\text { - Perceived } \\
\text { enjoyment }\end{array}$ & $\begin{array}{l}\text { - Conceptualized DFI as multidimensional } \\
\text { construct formed by tourists' cognitive } \\
\text { and affective evaluations. } \\
\text { - Proposed CFI attributes that are largely } \\
\text { relevant to the cuisine attributes of other } \\
\text { destinations. Attributes related to local } \\
\text { cuisine and culture as verified by local } \\
\text { chefs. } \\
\text { - Found positive relationship between DFI } \\
\text { and satisfaction. } \\
\text { - Identified perceived image of local cuisine } \\
\text { and level of satisfaction vary across } \\
\text { tourists from different European } \\
\text { regions. } \\
\text { - Tested full model of DFI } \\
\text { Limitation: } \\
\text { - The dimension of CFI is limited to local } \\
\text { cuisine image. Lack of examination of } \\
\text { other aspects of food tourism, e.g., people, } \\
\text { dining places, food environment, and } \\
\text { activities. }\end{array}$ \\
\hline
\end{tabular}


Table I. (continued)

\begin{tabular}{|c|c|c|c|c|c|c|c|}
\hline \multirow[b]{2}{*}{ Author (year) } & \multirow[b]{2}{*}{ Aims } & \multirow[b]{2}{*}{ Research Instrument } & \multirow{2}{*}{$\begin{array}{c}\text { Statistical } \\
\text { Analysis }\end{array}$} & \multicolumn{3}{|c|}{$\begin{array}{c}\text { Determinants and measurement of Destination } \\
\text { Food Image (DFI) }\end{array}$} & \multirow[b]{2}{*}{ Contributions / Limitation } \\
\hline & & & & CFI & AFI & INT & \\
\hline $\begin{array}{l}\text { Lertputtarak } \\
(2012)\end{array}$ & $\begin{array}{l}\text { Thai food: } \\
\text { Investigated the relationship } \\
\text { between food image and } \\
\text { intention to revisit. } \\
\text { Testing: } \\
\text { Cognitive-conative } \\
\text { components } \\
\text { Hypothesis I: } \\
\text { CFI } \rightarrow \text { INT }\end{array}$ & $\begin{array}{l}\text { Survey - international } \\
\text { tourists who visited } \\
\text { the destination and } \\
\text { tried the local cuisine } \\
(\mathbf{n = 4 7 6 )}\end{array}$ & $\begin{array}{l}\text { (i) mean } \\
\text { score } \\
\text { (ii) multiple } \\
\text { regression }\end{array}$ & $\begin{array}{l}\text { Cognitive } \\
\text { (19 items) } \\
2 \text { dimensions: } \\
- \text { food image } \\
\text { - restaurant image }\end{array}$ & - Not tested & $\begin{array}{l}\text { Conative } \\
\text { - Intention to } \\
\text { revisit }\end{array}$ & $\begin{array}{l}\text { - Conceptualized DFI as a single- } \\
\text { dimensional construct formed by } \\
\text { tourists' cognitive evaluations. } \\
\text { - Proposed CFI focused on food and } \\
\text { restaurant dimensions. } \\
\text { - Found a positive relationship between } \\
\text { CFI and revisit intention. } \\
\text { Limitation: } \\
\text { - The dimension of CFI is limited to local } \\
\text { cuisine image. Lack of examination of } \\
\text { other aspects of food tourism, e.g., people, } \\
\text { dining places, food environment, and } \\
\text { activities. }\end{array}$ \\
\hline Kim et al. (20I2) & $\begin{array}{l}\text { Korean food: Examined } \\
\text { the impact of a Korean } \\
\text { Cuisine drama on } \\
\text { potential Chinese tourists' } \\
\text { perceptions of food image, } \\
\text { and intention to visit. } \\
\text { Testing: } \\
\text { Hypothesis I: } \\
\text { CFI } \rightarrow \text { OFI } \rightarrow \text { INT } \\
\text { Hypothesis 2: } \\
\text { CFI } \rightarrow \text { INT } \\
\text { Hypothesis 3: } \\
\text { OFI } \rightarrow \text { INT }\end{array}$ & $\begin{array}{l}\text { Survey - Chinese } \\
\text { residents who live in } \\
\text { Shanghai and Beijing, } \\
\text { and who dined at } \\
\text { Korean restaurants } \\
(n=577)\end{array}$ & $\begin{array}{l}\text { (i) EFA } \\
\text { (ii) CFA } \\
\text { (iii) SEM }\end{array}$ & $\begin{array}{l}\text { Cognitive } \\
\text { (12 items) } \\
3 \text { dimensions: } \\
\text { - health menu } \\
\text { - food culture } \\
\text { - variety/harmony }\end{array}$ & - Not tested & $\begin{array}{l}\text { Conative } \\
\text { - Intention to } \\
\text { visit }\end{array}$ & $\begin{array}{l}\text { - Measured CFI based on a Korean } \\
\text { Cuisine drama, and provided insights into } \\
\text { storytelling for food tourism branding. } \\
\text { - Tested overall food image of a } \\
\text { destination (OFI) as a mediator for image } \\
\text { formation and visit intention. } \\
\text { Limitation: } \\
\text { - CFI items focused on few characteristics } \\
\text { of Korean cuisine, lack of examination of } \\
\text { other aspects of food attributes. } \\
\text { - Affective food image was not evaluated. }\end{array}$ \\
\hline
\end{tabular}

Note: CFI = cognitive food image; AFI = affective food image; OFI = overall destination food image; INT = intention; SAT = satisfaction; EFA = exploratory factor analysis; CFA = confirmatory factor analysis; SEM = structural equation modelling. 
Table 2. Cognitive Image of Food in Destination (Extracted from Lai, Khoo-Lattimore, and Wang 20I7).

\begin{tabular}{|c|c|c|}
\hline Dimension & Definition & References \\
\hline Place and geographic environment & $\begin{array}{l}\text { This dimension indicates the source of food } \\
\text { and the variations of climate, growing } \\
\text { seasons, topography, and soil that impact } \\
\text { crops cultivation, fishery, and livestock } \\
\text { production. }\end{array}$ & $\begin{array}{l}\text { Hjalager and Corigliano 2000; Lin, } \\
\text { Pearson, and Cai 201 I; Bessière } 2013\end{array}$ \\
\hline Food and cuisine culture & $\begin{array}{l}\text { This dimension characterizes food as a } \\
\text { cultural element, along with local culture, } \\
\text { history/heritage, customs, religion, } \\
\text { ethnicity, uniqueness of local cuisine and } \\
\text { dishes, aesthetic appeal, authenticity, and } \\
\text { fashionable eating experiences. }\end{array}$ & $\begin{array}{l}\text { Chang, Kivela, and Mak 20I I; Lertputtarak } \\
2012\end{array}$ \\
\hline Food and people & $\begin{array}{l}\text { This dimension consists of social attributes } \\
\text { that connect people to their culture and } \\
\text { ethnic groups through similar food-related } \\
\text { patterns or lifestyle. }\end{array}$ & Lin 2009; Frochot 2003 \\
\hline Food quality & $\begin{array}{l}\text { This dimension is concerned with hygiene } \\
\text { and the functional value of food, which } \\
\text { includes sensory qualities (e.g., taste, } \\
\text { appearance, smell, freshness, and texture), } \\
\text { promised quality, price value, food safety, } \\
\text { health and nutrition, and quality food } \\
\text { labeling standards. }\end{array}$ & $\begin{array}{l}\text { Seo and Yun 20I5; Peštek and Cinjarevic } \\
\text { 20I4; Lin, Pearson, and Cai 20II }\end{array}$ \\
\hline Dining places/ restaurants & $\begin{array}{l}\text { This dimension comprises situational factors } \\
\text { of a food environment, such as variety of } \\
\text { dining options (e.g., restaurants, farmers' } \\
\text { markets, street markets), attractiveness } \\
\text { of dining places (e.g., atmosphere, friendly } \\
\text { service, and easy access to place/location } \\
\text { and information). }\end{array}$ & Karim and Chi 20I0; Smith and Xiao 2008 \\
\hline Food activities & $\begin{array}{l}\text { This dimension refers to food tours, cooking } \\
\text { classes, food festivals and events that are } \\
\text { offered at destinations }\end{array}$ & $\begin{array}{l}\text { Smith and Xiao 2008; Lin, Pearson, and } \\
\text { Cai 201I }\end{array}$ \\
\hline
\end{tabular}

Research has raised questions about the relationship between cognitive and affective images, whether a food image is formed through individual beliefs, knowledge, and thoughts (cognitive-based image) or by emotion (affectivebased image) (Lai, Khoo-Lattimore, and Wang 2017), as well as whether the relationship varies across groups, for instance between high- and low-neophobia groups. An understanding of the relationship is critical to the tailoring of image projection strategies for different market segments and requires identifying the influence of cognitive and emotional appeals on decision making. Together, these studies demonstrate an absence of comprehensive models that consider all image components - cognitive, affective, and conative- of food in destinations.

More recently, research has sought to synthesize the host and tourist perspectives to develop a conceptual narrative relating to food and cuisine image formation and role (Lai, Khoo-Lattimore, and Wang 2017). This research considered 21 key studies and argued that the food images of tourists and hosts differed, and therefore indicators and constructs used to measure food image were inconsistent. For instance, host image studies found provenance/origin of food, farming, fishery, and food festival to be prominent attributes (Che 2006; Lee and Arcodia 2011), but few tourist-oriented studies tested these attributes. Similarly attributes important to tourists, such as diverse culture cuisines, food attractiveness, and variety of restaurants, were not discussed in the host studies (Lertputtarak 2012; Chang, Kivela, and Mak 2011; Seo and Yun 2015). Further, evaluations of food image have been mainly cognitive and focused on 40 attributes of food imagery categorized into six dimensions based on the nature of food tourism: food environment, food and cuisine culture, people, quality, dining places, and food-related activities (Lai, Khoo-Lattimore, and Wang 2017) (Table 2).

This study focuses on the conceptualization of food image and builds on image-formation literature. Two competing models have been tested: the Gartner (1994) model, which shows a consensus about the cognitive-affective-conative image formation process, and the Baloglu and McCleary (1999) model, which hypothesizes the overall image of food destination as a mediator. However, preliminary empirical results from this study show that the latter model was inferior 
to the former and that the effect of the overall image was not significant- $\mathrm{a}$ finding that contradicts the theoretical argument for, and the findings in previous studies of, a positive effect of overall image on conative behavior (Peštek and Cinjarevic 2014; Kim et al. 2012). Thus, this investigation focuses on a model that builds on Gartner's (1994) conceptual variables design suggesting that food image is both cognitively and affectively constructed, and highlights the model's impact on tourist behavior. The framework posits:

Hypothesis 1: Cognitive food image is positively related to affective food image.

Hypothesis 2: Affective food image is positively related to visit intention.

Hypothesis 3: Cognitive food image is positively related to visit intention.

\section{Food Neophobia as a Tourist Personality Trait}

The food tourism literature suggests that tourists' personality traits play a critical role in their food-related decisions, perceptions, and attitudes toward food destinations (Getz et al. 2014; Peštek and Cinjarevic 2014; Seo and Yun 2015). Studies of food-related personality traits tend to focus on the effect of these traits on tourists' interest, motivation, and participation in destination food-related activities (Mak et al. 2017; Wu et al. 2016). To many tourists, eating local food is a way of experiencing the local culture, traditions, and innovations (Boniface 2003). However, not all tourists consider food as an attraction, and instead may view it as an unfamiliar construct that impedes a positive experience in a culturally unfamiliar setting (Cohen and Avieli 2004).

The concept of food neophobia has been researched extensively since the early investigation of people's contradictory attitudes toward new food (Rozin 1976). Since then, neophobia has been discussed as a personality trait in the fields of psychology and sociology (Muhammad et al. 2016; Rozin 1996; Pliner and Hobden 1992), health science (Helland et al. 2017; Hwang and Lin 2010), and tourism (Ji et al. 2016; Kim, Suh, and Eves 2010; Mak et al. 2017).

While tourists often desire to try food from around the world and want to create holiday memories based on food, some tourists feel ambivalence toward unfamiliar foreign cuisine. Evidence suggests that tourists' attitudes toward destination food and cuisine are usually shaped by two contrasting personality traits: food neophobia and novelty seeking (Chang, Kivela, and Mak 2010; Ji et al. 2016). Strong food neophobia refers to an irrational fear or dislike of anything new, as individuals who are neophobic tend to avoid exotic, unknown, or novel food, or have a low familiarity with foreign cuisine (Fischler 1988; Mak et al. 2017). In contrast, low food neophobia denotes novelty-seeking (neophilia) individuals (neophiles) who enjoy food, are willing to try new food, and consider food experience to be an essential part of life, and who usually have a broader food knowledge
(Getz et al. 2014; Mak et al. 2017). These personality traits have been found to correlate strongly with a tourist's internal instincts, values, and beliefs, which are shaped by culture and personal experience (Rozin 1976; Ritchey et al. 2003). Consistent with this conceptualization, in this study the term food neophobia refers to a tourist's personality traits (or psychological responses) that give rise to individual ways of acting and thinking with regard to destination food.

Researchers have noted that food neophobia plays a vital role in moderating tourists' food-related decisions. Empirical studies have found that tourists with high food neophobia tend to have negative beliefs and attitudes toward local food consumption, have a high level of concern for food safety, and lack familiarity with the host culture and dining etiquette (Chang, Kivela, and Mak 2011; Wu et al. 2016). A study of Chinese tourists' dining behavior in Australia argued that food neophobia could exert a negative moderating effect on tourist motives to attend destination food events and festivals (Kim, Suh, and Eves 2010).

These perspectives raise questions as to whether potential differences exist between visitors with high neophobia and those with low neophobia in their views of food image before visiting a place, as well as questions as to how their perceptions of a food destination are formed. Therefore, food neophobia should be considered in the study of destination food image.

\section{Methods}

This study adopted a sequential multimethod approach to develop a research instrument and collect empirical data in two phases. The first phase involved a survey of food tourism stakeholders. The second phase consisted of a quantitative survey of prospective Chinese tourists (Figure 1).

\section{Stakeholder Survey and Results}

The purpose of the stakeholder survey was twofold: (1) to assess the attributes derived from the literature and their applicability to food tourism in Australia, and (2) to seek further insight into potential moderators of food image formation for Australia as a food destination for the Chinese market. These components were critical to informing the quantitative survey that followed. The survey was semistructured, containing closed and open questions that required stakeholders to rate the importance of the 40 attributes used in promoting Australia's food in tourism and then to comment on the uniqueness and identity of Australia as a food destination. Items also sought to reveal perceptions and food-related behavior of Chinese travelers. Eighteen industry stakeholders participated through an online survey. The stakeholders were recruited through an expert sampling method and included specialists who were directly or indirectly involved in planning Australia's food and wine campaign. Those most directly involved were tourism consultants 


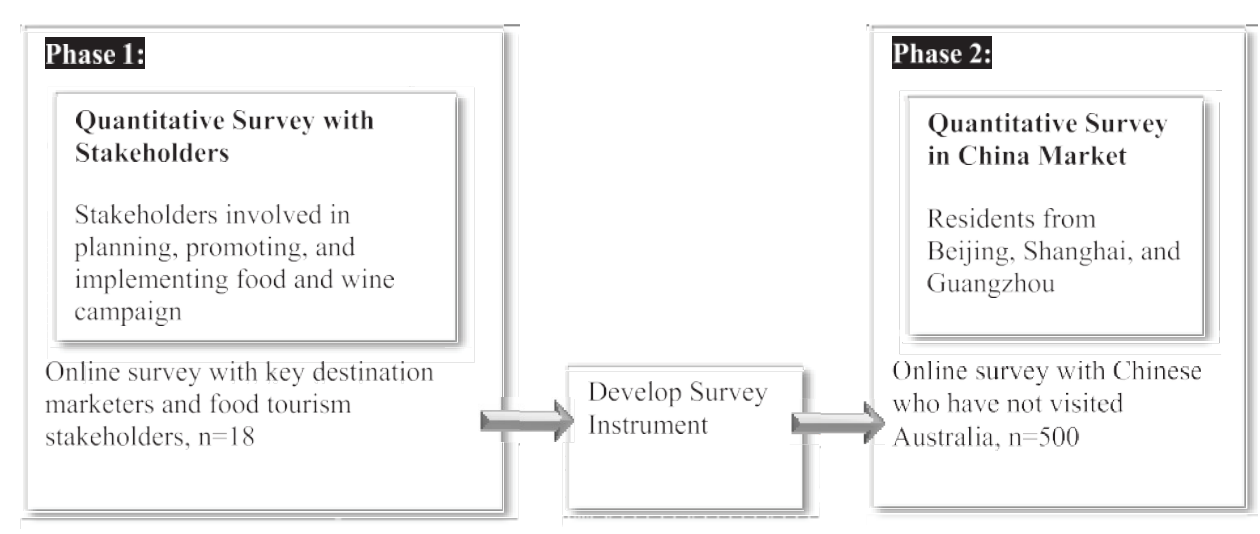

Figure I. Sequential multi-method approach.

who write the food and wine tourism strategy for Tourism Australia, chefs who play the role of ambassadors for Australia's food tourism, and destination marketers who promote and encourage corporate travelers from China to choose Australia as their preferred destination. Stakeholders who were indirectly involved were chefs and food and beverage operators who provide Australian food experiences in restaurants and promote food through the tourism chain.

Answers to the closed questions were analyzed using simple descriptive statistics of mean scores, and qualitative comments were thematically analyzed using Nvivo. Data derived from stakeholders in Phase 1 confirmed the relevance of the food destination attributes identified from the literature, with the mean score for the 40 attributes ranging from 4.53 to 6.59 out of 7 , although perceptions of the relative importance of the attributes varied to some extent (Appendix 1). In addition, when stakeholders were asked to describe the key challenges in marketing Australian food and cuisine to the Chinese tourist market, food neophobia emerged as an important influence on Chinese tourists' food-related behavior:

Chinese people like comfortable surroundings and tastes that they are used to, such as Chinese food using a Chinese method of cooking. (Chris, food and beverage provider)

The Chinese tourist likes to eat mainly Asian meals in their trip to Australia. They even prefer to taste Australian fresh seafood in a Chinese restaurant. (Gina, coordinator of a tourism attraction)

Chinese FIT (free independent traveler) tourists seem to be . . . more open to trying new things. My opinion is that mass Chinese tourists are less inclined to try new things or have an open mind. (Bruce, researcher of independent restaurants in Australia)

On the basis of the stakeholder survey results (phase 1), we proposed a conceptual model showing that tourist behavioral intention (INT) evolves and forms from the interaction between the cognitive food image (CFI) and affective food image (AFI) constructs. The model suggests that the CFI directly influences intention to visit Australia as a food destination and also has an effect on the AFI. Further, we hypothesized that food neophobia moderates the set of relationships between cognitive image, affective image, and visit intention, differing between high or low food neophobia levels.

Hypothesis 4: Food neophobia moderates the relationships between cognitive image, affective image, and visit intention.

Cognitive Food Image as a Formative Measurement. As discussed in the introduction, formative indicators collectively cause a construct. Hence, the direction of causality is from indicators to construct (Coltman et al. 2008; Hair, Hult, Ringle, and Sarstedt 2017), as shown in Figure 2.

We assessed the formative model of cognitive food image from the theoretical and empirical perspectives using the frameworks suggested by Coltman et al. (2008) and Hair, Hult, Ringle, and Sarstedt (2017), which emphasize three criteria: nature of the construct, direction of causality, and characteristics of indicators. First, regarding its nature, the cognitive construct is formed from multiple food dimensions and attributes in which indicators are treated as causes of the latent construct. The cognitive component of food image builds upon a great variety of destination aspects such as the environment, sociocultural identity, and experiential dimensions of food tourism, which collectively determine the tourist's image of a destination and its food tourism and subsequently influence tourists' choice of food experience (Getz et al. 2014; Frochot 2003; Long 2004; Boniface 2003). Tourists' perceptions of a destination's food and cuisine can be positive, negative, or neutral (Getz et al. 2014). These perceptual images shape tourists' sense of reality, which then drives attitude and behavior and influences decision making. Arguably, removing any of these dimensions would change the conceptual interpretation of food tourism characteristics. 
Reflective Indicators (Effect Model)

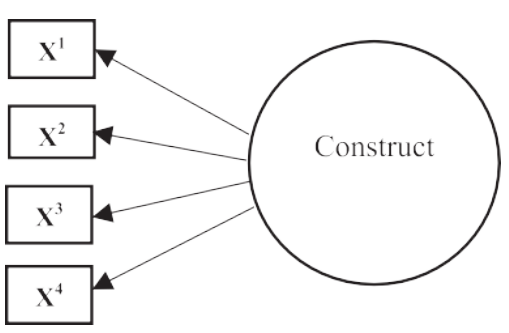

Formative Indicators (Causal Model)

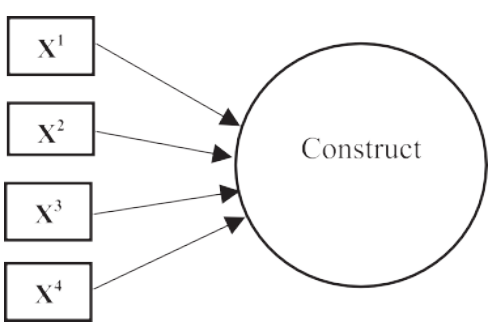

Figure 2. Reflective and formative measurement model (adapted from Hair, Hult, Ringle, and Sarstedt 2017).

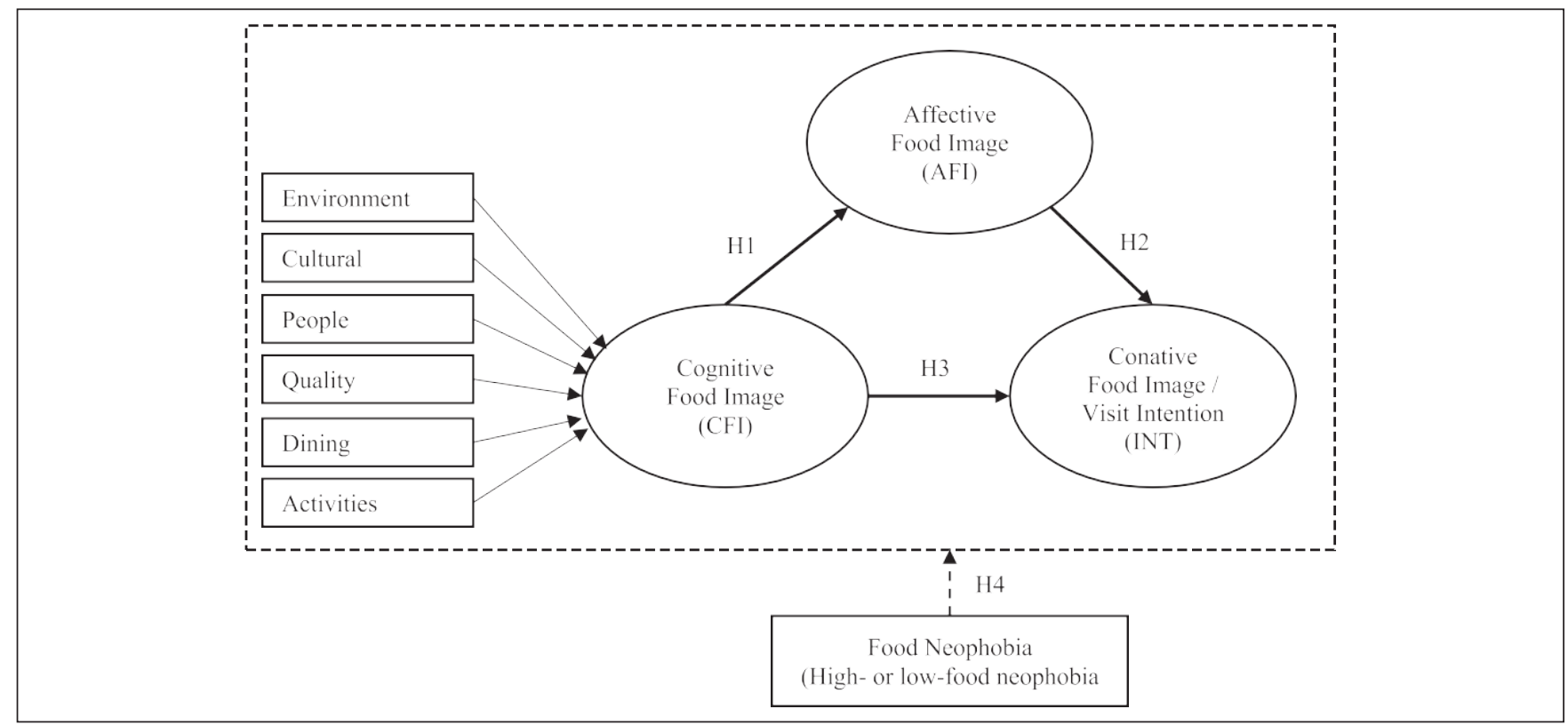

Figure 3. Research model for Destination Food Image (DFI).

Second, in terms of the direction of causality, as we previously argued (Figure 2), a more logical approach is to view the multidimensional food attributes as forming tourists' image perceptions, rather than the other way around. Third, regarding the characteristics of indicators, the cognitive food image consists of functional and symbolic attributes that represent the tangible and intangible dimensions of a place's food. Hence, these attributes contribute differently to forming an underlying construct, suggesting that indicators used to measure the cognitive construct are not interchangeable and need not share a common theme (Coltman et al. 2008; do Valle and Assaker 2016; Fornell and Bookstein 1982). For example, the three indicators typically used to measure food-related activities are food and gourmet tours, cooking classes, and food festivals and events. While these indicators may be combined to make up a cognitive construct, they vary greatly and are not interchangeable (Getz et al. 2015; S. Kim et al. 2010). The relationship between them is formative, and does not assume any direct effect as each may exhibit a different behavioral pattern given that tourists have different preferences and interests in food-related activities and experiences.

Furthermore, the list of cognitive food destination indicators was derived from the literature from both consumer and stakeholder perspectives. While consumer-related indicators have been empirically tested, stakeholder-related indictors have not, and their generalizability is unclear. In addition, Australia has not been extensively investigated as a food tourism destination and Chinese travelers have not been traditionally regarded as a promising segment for food tourism. Therefore, the aforementioned theoretical rationale and stakeholders' expert opinions were the subjects of our first examination of the validity of formative indicators for testing the cognitive food image construct. 
Affective and Conative Food Image as a Reflective Measurement. This study follows the reflective model (Sparks 2007; Seo and Yun 2015; Pike and Ryan 2004) in operationalizing the affective and conative measures in social science literature, where these image components were treated as independent measures with well tested measurement scales. Figure 3 presents the proposed research model.

\section{Quantitative Survey}

In phase 2, we conducted an online questionnaire survey. The sampling frame included prospective Chinese travelers who had not visited Australia. The survey followed Tourism Australia's current target market strategy to focus on the middle- and upper-middle class earners who live in China's most prominent cities (Tourism Australia 2016). Access to the sample was through Qualtrics' research panel, which provided a sample that met two criteria: (1) equal distribution across genders and (2) equal distribution across the three main cities of Shanghai, Beijing, and Guangzhou, which currently contribute about $45.5 \%$ of total Chinese visitors to Australia (Tourism Australia 2018).

Questionnaire and measurement scales. The questionnaire included five sections on cognitive image (40 items), affective image (8 items), intention (5 items), food neophobia personality traits (6 items), and tourists' sociodemographic profile and travel characteristics. The tourists' sociodemographic data were measured with structured items based on possible answers provided, while all other items were measured using a Likert-type scale $(1=$ strongly disagree to $7=$ strongly agree). Appendix 2 presents a full list of measurement scales.

Cognitive food image. CFI was operationalized through 40 attributes of food images classified into six dimensions: (1) place and geographic environment, (2) food and cuisine culture, (3) food and people, (4) food quality, (5) dining places/ restaurants, and (6) food activities. The measures were built on prior work (Lai, Khoo-Lattimore, and Wang 2017), with further empirical support from the stakeholders described earlier (Appendix 2).

Affective food image. The study was derived from an eightitem measure of AFI from existing literature based primarily on the pleasure, arousal, and dominance (PAD) model and anticipated affective attitude in line with the theory of planned behavior (TPB). The subset items adopted from the PAD comprised excited, satisfied, and aroused (Sparks 2007), to which we added relaxed, a descriptor that is often applied to dining experiences in Australia (Tourism Australia 2017). Items adopted from TPB's affective attitude included enjoyable, good, fun, and pleasant (Sparks and Pan 2009; Seo and Yun 2015).
Conative food image/Intention. INT was operationalized as potential tourists' future behavioral intention, measured using five indicators of participants' stated intent to visit Australia as a food tourism destination and their recommendation behaviors. The time frame used in the prediction of visit intention was "the next 24 months," as overseas travel is likely to occur once every two years for the Chinese market (Sparks 2007).

Food neophobia. Six food neophobia items were adopted from the work of Kim, Suh, and Eves (2010) to measure the construct as a personality trait.

Procedure. The questionnaire was constructed in English and translated into Chinese by the first author. To ensure accuracy, grammatical correctness, and sensitivity to cultural variation, the survey was reviewed by six bilingual tourism scholars who are native Chinese speakers. Several issues were addressed, such as maintaining the intended meaning of the questions and matching the semantic content and structure across languages in both question and answer scales. We also included one attention check to identify unengaged responses. A pretest was conducted with 40 respondents (April 2017) for readability and clarity, which led to a few minor revisions to the questionnaire. Full data collection took a month and was completed in May 2017. The survey returned a total of 522 completed questionnaires. Two cases were eliminated owing to unengaged responses and low length of completion time. Owing to the sensitiveness of PLS to the effect of outliers, we removed outliers on the basis of inspections of boxplot, univariate, and multivariate analysis. The procedure resulted in the removal of 20 responses and yielded a sample of 500 valid responses for data analysis.

\section{Results}

\section{Demographic Profile}

Table 3 presents full profiles. A relatively even distribution existed across gender, with an almost same number of respondents from each city. Most respondents were married $(80 \%)$. Respondents tended to fall in the young $(45 \%)$ to middle-aged groups (44\%). The sample was skewed toward highly educated Chinese, with $72 \%$ having completed a bachelor's degree, and more than $50 \%$ of respondents reported monthly household incomes above Chinese Yuan $¥ 16,000$ (approximately US\$2,530).

\section{Partial Least Squares Structural Equation Modeling (PLS-SEM)}

We used partial least squares (PLS) regression to analyze the data in a structural equation model (SEM) using SmartPLS 
Table 3. Profile of Survey Respondents.

\begin{tabular}{|c|c|c|}
\hline & Frequency $(\mathrm{N}=520)$ & Percentage \\
\hline \multicolumn{3}{|l|}{ Gender } \\
\hline Male & 244 & 48.8 \\
\hline Female & 256 & 51.2 \\
\hline \multicolumn{3}{|l|}{ City } \\
\hline Beijing & 167 & 33.4 \\
\hline Shanghai & 169 & 33.8 \\
\hline Guangzhou & 164 & 32.8 \\
\hline \multicolumn{3}{|l|}{ Age, years } \\
\hline$>18-29$ & 225 & 46.1 \\
\hline $30-39$ & 222 & 43.7 \\
\hline $40-49$ & 23 & 4.6 \\
\hline $50-60$ & 30 & 5.6 \\
\hline \multicolumn{3}{|l|}{ Income (monthly) } \\
\hline$¥ 8000-¥ 16,000$ & 217 & 43.4 \\
\hline$¥ 16,001-¥ 25,000$ & 117 & 23.4 \\
\hline$¥ 25,001-¥ 40,000$ & 108 & 21.6 \\
\hline$>¥ 40,001$ & 58 & 11.6 \\
\hline \multicolumn{3}{|l|}{ Marital } \\
\hline Married & 400 & 80.0 \\
\hline Never married & 100 & 20.0 \\
\hline \multicolumn{3}{|l|}{ Child } \\
\hline None & 128 & 25.6 \\
\hline \multicolumn{3}{|l|}{ Qualification } \\
\hline High school graduate & 3 & 0.6 \\
\hline College & 14 & 2.8 \\
\hline Bachelor's degree & 360 & 72.0 \\
\hline Master's degree & 105 & 21.0 \\
\hline Doctoral degree & 18 & 3.8 \\
\hline \multicolumn{3}{|l|}{ Employment } \\
\hline Working full-time & 464 & 92.8 \\
\hline Working (self-employed) & 21 & 4.2 \\
\hline Part-time/casual & 5 & 1.0 \\
\hline
\end{tabular}

version 3 software. The traditional covariance-based SEM (CB-SEM) method requires the model to be identified before it can converge (Sarstedt et al. 2016). However, in the preliminary analysis of the normality of data using the SPSS Kolmogorov-Smirnov test (KS test), the results suggested that our data set was not normally distributed across all the variables $(p<0.001)$. Furthermore, the proposed destination food image model investigation was to some extent both exploratory and confirmatory, since it involved some indicators of known and many other indicators of unknown composition (i.e., indicators that have never been empirically validated). Therefore, the traditional SEM method was deemed unsuitable (Sarstedt et al. 2016; Hair, Hult, Ringle, Sarstedt, et al. 2017), and PLS-SEM was used to analyze the data for predicting the key target construct and for testing the causal relationships between constructs using both reflective (consequent) and formative (causal) outer model evaluation (Lowry and Gaskin 2014; Diamantopoulos and Winklhofer 2001; do Valle and Assaker 2016).
We used a two-stage method to build a second-order model formative construct (or hierarchical component model) to reduce model complexity (van Riel et al. 2017). First, we assessed the validity of the first-order models, the formative construct, and cognitive food image (CFI) as well as the reliability and validity of the two reflective constructs: affective food image (AFI) and intention (INT) (Appendix 3 ). We also tested the second-order model using the latent construct composite scores of the first-order constructs of CFI and evaluated the validity of the second-order structure CFI. Lastly, we assessed the structural model and performed multi-group analysis to investigate the moderating effect of food neophobia.

\section{Measurement Model (Outer Model)}

Reflective Measurement Model. AFI and INT were measured as reflective constructs, and in the reflective measurement model we confirmed their reliability and validity at both the individual indicator (i.e., convergent validity) and construct levels (i.e., discriminant validity) (Table 4). Mean values of AFI (6.206) and INT (6.069) suggested positive evaluation of these constructs by Chinese tourists. The evaluation of the individual reliability of each indicator was based on factor loadings above 0.70 and a bootstrapping significance test estimated from 5,000 subsamples (Hair, Hult, Ringle, and Sarstedt 2017). Results showed that all five outer loadings of the INT construct were well above the threshold value. Four AFI outer loadings were slightly below the critical value, with the lowest indicator reliability being 0.642. We deemed this acceptable as the application of these indicators in food tourism research was new, and was guided by outer loading relevant testing (Hair, Hult, Ringle, and Sarstedt 2017). Furthermore, results from the bootstrapping test showed a high level of significance for all loadings, suggesting that all indicators significantly reflected their underlying constructs, and indicating high reliability for indicators.

The Cronbach's alpha for both the AFI and INT constructs was higher than the threshold of 0.70 . The average variance extracted (AVE) values for AFI and INT constructs exceeded the threshold value of 0.50. Composite reliabilities for the two constructs were 0.893 and 0.896 , both above the threshold of 0.70 , indicating reliability (Fornell and Larcker 1981).

Discriminant validity was confirmed using the FornellLarcker criterion, which showed that the square root of the AVE of AFI construct was 0.715 , which was higher than its highest correlation with the INT construct at 0.643 . We also used a more sophisticated method of heterotrait-monotrait ratio of correlations (HTMT) (Ab Hamid, Sami, and Sidek 2017; Henseler, Ringle, and Sarstedt 2015) and the HTMT value of 0.741 was below the recommended value of 0.85 (Tables 5 and 6). 
Table 4. Reflective Measurement Model Assessment.

\begin{tabular}{|c|c|c|c|c|c|c|c|}
\hline Constructs & Indicators & Outer Loadings & $t$ Value & $\mathrm{a}$ & CR & AVE & $R^{2}$ \\
\hline \multirow{8}{*}{$\begin{array}{l}\text { Affective food } \\
\text { image (AFI) } \\
\quad(M=6.206)\end{array}$} & Excited & $0.699 * * *$ & 29.472 & 0.863 & 0.893 & 0.511 & 0.528 \\
\hline & Satisfied & $0.731 * * *$ & 30.884 & & & & \\
\hline & Aroused & $0.642 * * *$ & 23.540 & & & & \\
\hline & Enjoyable & $0.737 * * *$ & 31.537 & & & & \\
\hline & Fun & $0.753 * * *$ & 36.354 & & & & \\
\hline & Pleasant & $0.765^{* * *}$ & 35.684 & & & & \\
\hline & Good & $0.698 * * *$ & 26.154 & & & & \\
\hline & Relax & $0.686 * * *$ & 25.895 & & & & \\
\hline \multirow[t]{5}{*}{$\begin{array}{r}\text { Intention (INT) } \\
\quad(M=6.069)\end{array}$} & $\begin{array}{l}\text { I intend to choose Australia as a food } \\
\text { destination in the near future. }\end{array}$ & $0.795 * * *$ & 41.485 & 0.856 & 0.896 & 0.634 & 0.607 \\
\hline & $\begin{array}{l}\text { I will travel to Australia as a destination } \\
\text { because of its food. }\end{array}$ & $0.775 * * *$ & 42.813 & & & & \\
\hline & $\begin{array}{l}\text { I intend to travel to Australia and taste } \\
\text { its food. }\end{array}$ & $0.836 * * *$ & 36.574 & & & & \\
\hline & $\begin{array}{l}\text { I am willing to eat Australian food in the } \\
\text { near future. }\end{array}$ & $0.776 * * *$ & 57.699 & & & & \\
\hline & $\begin{array}{l}\text { I am willing to recommend people to } \\
\text { visit Australia for its food. }\end{array}$ & $0.797 * * *$ & 40.650 & & & & \\
\hline
\end{tabular}

Note: $\mathrm{a}=$ Cronbach's alpha; $\mathrm{CR}=$ composite reliability; $\mathrm{AVE}=$ average variance extracted; $R^{2}=$ explained variance.

***Significant at $1 \%$.

Formative Measurement Model. Table 7 presents results on the formative model. The mean values of the six dimensions vary between 5.753 and 6.062, and the model yields strong evidence for a formative model based on the approach of Hair, Hult, Ringle, and Sarstedt (2017). We confirmed that convergent validity for CFI is supported. The redundancy analysis was performed by creating a structural model linking the formative construct with another construct of the first-order model that is theoretically related and operationalized through a reflective measure. For example, a structural path was created by linking a food culture construct (modeled as a formative measure and an independent variable) with a people construct (modeled as a reflective measure and a dependent variable). Results showed that the strength of path coefficients linking the designated set of formative constructs range from 0.7 to 0.8 , meeting the threshold of 0.7 , and $R^{2}$ values of more than 5, ranging from 0.55 to 0.81 (Hair, Hult, Ringle, and Sarstedt 2017).

We then tested the content validity of the construct measures and each indicator's relative contribution to the construct (i.e., the indicator weights) and collinearity statistics by examining variance inflation factors (VIFs) (Hair et al. 2014). The results suggested that 10 of the 40 indicators were nonsignificant weights with a tolerance value smaller than 0.20 ( $p>0.05$ ) (Hair, Hult, Ringle, and Sarstedt 2017). Most of these indicators were from the cultural construct, measured by 13 indicators. A large number of formative indicators may lead to low or even nonsignificant weights (Cenfetelli and Bassellier 2009). We decided to retain the nonsignificant indicators at this exploratory stage because (1) all indicators had a relatively high and significant outer loading $(>0.50)$ with the exceptions of menu and eating style (loading $>0.45$ ); (2) removal of these indicators led to a decrease in outer weights of indicators among other indicators and reduced the effect size $f^{2}$ and model fit measures; (3) this allowed the theory to override the statistics; and (4) all VIF values met the requirement of a value below 5 (Hair, Hult, Ringle, and Sarstedt 2017).

Second-order model results. We extracted the latent construct scores from the first-order construct CFI to build the secondorder composite model (van Riel et al. 2017), in which CFI was composited and had a formative-formative relationship in the path model. The results indicated that three of six outer weights - environment, cultural, and dining-were well above the critical value of 0.2 (Hair, Hult, Ringle, and Sarstedt 2017). The remaining three indicators-people, quality, and activities - were not statistically significant, but their outer loadings were well above the critical value of 0.50 (Table 8). The VIF value for the cultural dimension slightly exceeded the conservative rule of 5 (Hair, Hult, Ringle, and Sarstedt 2017), but was retained given its theoretical relevance, the recommendation of a more liberal cut-off of VIF value of 10 (O'Brien 2007; Diamantopoulos, Riefler, and Roth 2008), and the fact that culture was the most crucial indicator with the highest significant weight (0.412) across all the CFI indicators.

\section{Structural Model (Inner Model)}

The proposed structural model was evaluated through an examination of path coefficients, coefficient of determination 
Table 5. Discriminant Validity: Fornell and Lacker Criterion.

\begin{tabular}{|c|c|c|c|c|c|c|c|c|}
\hline & AFI & $\begin{array}{c}\text { CFI_- } \\
\text { Activities }\end{array}$ & $\begin{array}{c}\text { CFI_- } \\
\text { Cultural }\end{array}$ & $\begin{array}{l}\text { CFI_- } \\
\text { Dining }\end{array}$ & $\stackrel{\text { CFI_- }}{\text { Environment }}$ & ${ }_{\text {People }}^{\text {CFI_- }}$ & $\begin{array}{c}\text { CFI_- } \\
\text { Quality }\end{array}$ & INT \\
\hline $\mathrm{AFI}$ & 0.715 & & & & & & & \\
\hline CFI_Activities & 0.550 & FMM & & & & & & \\
\hline CFI_Cultural & 0.682 & 0.740 & FMM & & & & & \\
\hline CFI_Dining & 0.654 & 0.732 & 0.817 & FMM & & & & \\
\hline CFI_Environment & 0.649 & 0.619 & 0.762 & 0.717 & FMM & & & \\
\hline CFI_People & 0.608 & 0.687 & 0.796 & 0.756 & 0.669 & FMM & & \\
\hline CFI_Quality & 0.666 & 0.687 & 0.828 & 0.791 & 0.765 & 0.738 & FMM & \\
\hline INT & 0.643 & 0.627 & 0.736 & 0.708 & 0.625 & 0.638 & 0.646 & 0.796 \\
\hline
\end{tabular}

Note: $F M M=$ formative measurement model; $C F I=$ cognitive food image; $A F I=$ affective food image.

Table 6. Discriminant validity: Heterotrait-monotrait ratio of correlations (HTMT).

\begin{tabular}{lccccc}
\hline & Original sample & Sample Mean & Standard Deviation & $T$ Statistics & $p$ Value \\
\hline INT $\rightarrow$ AFI & 0.741 & 0.742 & 0.036 & 20.319 & 0.000 \\
\hline
\end{tabular}

Note: INT = intention; AFI = affective food image.

Table 7. Formative Measurement Model Assessment.

\begin{tabular}{|c|c|c|c|c|c|c|}
\hline \multirow{2}{*}{$\begin{array}{l}\text { Formative } \\
\text { Constructs }\end{array}$} & \multirow{2}{*}{$\begin{array}{l}\text { Formative } \\
\text { Indicators } \\
\text { (CFI) }\end{array}$} & \multicolumn{3}{|c|}{ Significant of Outer Weights } & \multirow{2}{*}{$\frac{\text { Bootstrapping }}{p \text { Value }}$} & \multirow{2}{*}{$\frac{\text { Collinearity }}{\text { Outer VIF }}$} \\
\hline & & Outer Weights & Outer Loading & $t$ Value & & \\
\hline \multirow{5}{*}{$\begin{array}{l}\text { Environment } \\
\qquad(M=6.062)\end{array}$} & CFII_clean & 0.479 & 0.860 & 9.088 & 0.000 & 1.595 \\
\hline & CFI2_farming & 0.185 & 0.681 & 3.727 & 0.000 & 1.464 \\
\hline & CFI3_fishery & $0.24 I$ & $0.70 \mathrm{I}$ & 4.770 & 0.000 & 1.431 \\
\hline & CFI4_coo & 0.201 & 0.709 & 3.616 & 0.000 & 1.520 \\
\hline & CFI5_abundance & 0.233 & 0.648 & 4.201 & 0.000 & 1.328 \\
\hline \multirow{13}{*}{$\begin{array}{l}\text { Cultural } \\
\qquad(M=5.896)\end{array}$} & CFI6_history & 0.077 & 0.652 & $\mathrm{I} .576$ & 0.106 & 1.671 \\
\hline & CFI7_local & 0.181 & 0.759 & 3.392 & 0.001 & 1.870 \\
\hline & CFI8_eating & 0.047 & 0.467 & 1.166 & 0.219 & 1.288 \\
\hline & CFI9_dish & 0.160 & 0.724 & 3.616 & 0.002 & 1.786 \\
\hline & CFII0_multicultural & -0.048 & 0.558 & 0.930 & 0.362 & $\mathrm{I} .578$ \\
\hline & CFIII_unique & 0.153 & 0.719 & 2.909 & 0.004 & 1.722 \\
\hline & CFII2_varietyfoods & 0.225 & 0.753 & 4.402 & 0.000 & 1.767 \\
\hline & CFII3_cuisine & 0.061 & 0.595 & 1.442 & 0.144 & 1.564 \\
\hline & CFII4_aesthetic & 0.116 & 0.675 & 2.769 & 0.007 & 1.630 \\
\hline & CFII5_religious & 0.053 & 0.522 & 1.363 & 0.161 & 1.415 \\
\hline & CFII6_exotic & 0.120 & 0.651 & 2.336 & 0.013 & 1.552 \\
\hline & CFII7_appealing & 0.157 & 0.777 & 3.362 & 0.001 & 2.043 \\
\hline & CFII8_wellknown & 0.115 & 0.692 & 2.374 & 0.015 & 1.773 \\
\hline \multirow{4}{*}{$\begin{array}{l}\text { People } \\
\qquad(M=5.753)\end{array}$} & CFII9_lifestyle & 0.352 & 0.685 & 6.433 & 0.000 & 1.211 \\
\hline & CFI20_status & 0.122 & 0.415 & 2.417 & 0.014 & 1.119 \\
\hline & CFI2I_chef & 0.435 & 0.790 & 7.930 & 0.000 & 1.359 \\
\hline & CFI22_friendly & 0.463 & 0.788 & 8.822 & 0.000 & 1.282 \\
\hline \multirow{7}{*}{$\begin{array}{l}\text { Quality } \\
\qquad(M=5.899)\end{array}$} & CFI23_tasty & 0.262 & 0.708 & 4.682 & 0.000 & 1.426 \\
\hline & CFI24_quality & 0.318 & 0.787 & 6.125 & 0.000 & 1.609 \\
\hline & CFI25_safety & 0.231 & 0.738 & 3.740 & 0.000 & 1.599 \\
\hline & CFI26_healthy & 0.219 & 0.727 & 3.733 & 0.000 & 1.601 \\
\hline & CFI27_digestable & 0.071 & 0.512 & 1.350 & 0.183 & 1.331 \\
\hline & CFI28_fresh & 0.206 & 0.723 & 3.585 & 0.000 & 1.582 \\
\hline & CFI29_price & 0.097 & 0.513 & 1.943 & 0.053 & 1.318 \\
\hline
\end{tabular}


Table 7. (continued)

\begin{tabular}{|c|c|c|c|c|c|c|}
\hline \multirow{2}{*}{$\begin{array}{l}\text { Formative } \\
\text { Constructs }\end{array}$} & \multirow{2}{*}{$\begin{array}{c}\text { Formative } \\
\text { Indicators } \\
\text { (CFI) }\end{array}$} & \multicolumn{3}{|c|}{ Significant of Outer Weights } & \multirow{2}{*}{$\frac{\text { Bootstrapping }}{p \text { Value }}$} & \multirow{2}{*}{$\begin{array}{l}\text { Collinearity } \\
\text { Outer VIF }\end{array}$} \\
\hline & & Outer Weights & Outer Loading & $t$ Value & & \\
\hline \multirow[t]{8}{*}{$\begin{array}{l}\text { Dining } \\
(M=5.82 \mathrm{I})\end{array}$} & $\begin{array}{l}\text { CFI30_- } \\
\text { Variety places }\end{array}$ & 0.231 & 0.724 & 4.265 & 0.000 & $\mathrm{I} .577$ \\
\hline & CFI3I_view & 0.265 & 0.735 & 5.359 & 0.000 & 1.526 \\
\hline & CFI32_street & 0.095 & 0.583 & 1.839 & 0.059 & 1.495 \\
\hline & CFI33_market & 0.256 & 0.700 & 5.307 & 0.000 & 1.422 \\
\hline & CFI34_menu & 0.028 & 0.454 & 0.617 & 0.536 & 1.293 \\
\hline & CFI35_staff & 0.254 & 0.708 & 4.993 & 0.000 & 1.523 \\
\hline & CFI36_access & 0.052 & 0.581 & 1.084 & 0.288 & 1.494 \\
\hline & CFI37_restaurant & 0.256 & 0.710 & 5.509 & 0.000 & 1.488 \\
\hline \multirow{3}{*}{$\begin{array}{l}\text { Activities } \\
(M=5.765)\end{array}$} & CFI38_tour & 0.627 & 0.891 & 11.370 & 0.000 & 1.339 \\
\hline & CFI39_cooking & 0.189 & 0.572 & 3.059 & 0.002 & 1.230 \\
\hline & CFI40_festival & 0.422 & 0.790 & 6.729 & 0.000 & 1.386 \\
\hline
\end{tabular}

Note: VIF $=$ variance inflation factors; $\mathrm{CFI}=$ cognitive food image. Grand mean $=5.873$. Estimates are based on bootstrapping with 5,000 subsamples. *** Significant at $1 \%$.

Table 8. Second-Order Model.

\begin{tabular}{|c|c|c|c|c|c|}
\hline \multirow[b]{2}{*}{ Formative CFI Indicators } & \multicolumn{3}{|c|}{ Significance of Weights } & \multirow{2}{*}{$\frac{\text { Bootstrapping }}{p \text { Value }}$} & \multirow{2}{*}{$\frac{\text { Collinearity }}{\text { Outer VIF }}$} \\
\hline & Outer Weights & Outer Loading & $t$ Value & & \\
\hline Environment $(M=6.062)$ & 0.202 & 0.859 & $3.640 * * *$ & 0.000 & 2.827 \\
\hline Cultural $(M=5.896)$ & 0.412 & 0.958 & $5.168 * * *$ & 0.000 & 5.197 \\
\hline People $(M=5.753)$ & 0.066 & 0.841 & I.I42 (ns) & 0.254 & 3.137 \\
\hline Quality (M = 5.899) & 0.072 & 0.885 & $\mathrm{I} .083$ (ns) & 0.279 & 4.097 \\
\hline Dining $(M=5.821)$ & 0.289 & 0.920 & $4.263 * * *$ & 0.000 & 3.938 \\
\hline Activities $(M=5.765)$ & 0.059 & 0.795 & 1.187 (ns) & 0.235 & 2.553 \\
\hline
\end{tabular}

Note: $\mathrm{CFI}=$ cognitive food image; VIF = variance inflation factor; ns = not significant. Results were based on bootstrapping with 5,000 subsamples. *** Significant at $1 \%$.

$\left(R^{2}\right)$, effect size $\left(f^{2}\right)$, and cross-validated redundancy $\left(Q^{2}\right)$ (So, Oh, and Min 2018; Hair et al. 2014). As shown in Table 9, all paths in the structural model were significant $(p<0.05)$, with CFI having a stronger effect on INT $(\beta=0.617)$ than AFI $(\beta$ $=0.197)$. The two constructs together explain $59.6 \%$ of the variance of the endogenous construct INT $\left(R^{2}=0.596\right)$. CFI also had a substantial impact on AFI $(\beta=0.721)$ and explains $52 \%$ of the variance of the AFI construct $\left(R^{2}=0.52\right)$. Overall, the structural model results suggested CFI as a stronger predictor of INT than AFI. Findings thus support hypotheses 1,2 , and 3 .

We then tested the predicting power of the model by assessing the goodness of model $R^{2}$ and effect size $f^{2}$. The $R^{2}$ values for AFI and INT were 0.520 and 0.596 , respectively, both above the suggested value of 0.26 (J. Cohen 1988). Further, in marketing research, effect sizes $\left(f^{2}\right)$ of $0.02,0.15$, and 0.35 , respectively, represent small, medium, and large effects of the exogenous construct (Cohen 1988). The path model showed two large effect sizes of CFI on AFI $\left(f^{2}=1.085\right)$ and INT $\left(f^{2}=0.452\right)$ and a small impact of AFI on INT $\left(f^{2}=0.046\right)$.
The Stone-Geisser test returned a $Q^{2}$ value of 0.502 for $\mathrm{AFI}$ and 0.577 for INT, both above zero, implying the model's high predictive relevance (Stone 1974; Geisser 1974). In addition, the structural model achieved an acceptable model fit, with a value of the standardized root mean square residual (SRMR) value of 0.011 , less than the recommended value of 0.08 , and an NFI value of 0.994, above the tolerance value of 0.90 (Hair, Hult, Ringle, and Sarstedt 2017).

\section{Multigroup Analysis}

We hypothesized in hypothesis 4 that food neophobia is a moderator of the relationships between cognitive image, affective image, and intention. The validated model was examined through multigroup analysis in PLS path modeling (PLS-MGA) to test this moderation effect. First, the food neophobia variable was transformed from a continuous to a categorical variable. As we were interested in identifying individuals who are "clearly" food-neophobic versus novelty seekers, a broadly adopted percentile split 
Table 9. Results of Structural Model.

\begin{tabular}{lccccc}
\hline Hypothesis & & $\begin{array}{c}\text { Path } \\
\text { Coefficients }\end{array}$ & $t$ Value & $\begin{array}{c}\text { Standard } \\
\text { Errors }\end{array}$ & $\begin{array}{c}95 \% \text { Confidence } \\
\text { Interval }\end{array}$ \\
\hline Hypothesis I & CFI $\rightarrow$ AFI & 0.721 & $27.313^{* * *}$ & 0.026 & $0.669,0.773$ \\
Hypothesis 2 & AFI $\rightarrow$ INT & 0.197 & $3.718^{* * *}$ & 0.053 & $0.087,0.293$ \\
Hypothesis 3 & CFI $\rightarrow$ INT & 0.617 & $13.094^{* * *}$ & 0.047 & $0.529,0.715$ \\
\hline
\end{tabular}

Note: $\mathrm{CFI}=$ cognitive food image; $\mathrm{AFI}=$ affective food image; INT = intention. $f^{2}$ is not provided for indirect effects. All estimates were based on a twotailed test; for bootstrapping with a two-tailed test, critical value of 1.96 (significant level $=5 \%$ ) was chosen. Subsamples were of 5,000.

$* * * p<0.001$.

Table 10. Results of Moderation Effects on Structural Model.

\begin{tabular}{|c|c|c|c|c|c|c|c|c|}
\hline \multirow[b]{2}{*}{ Hypothesis: Paths } & \multicolumn{2}{|c|}{$\begin{array}{l}\text { Original Model } \\
\qquad(n=500)\end{array}$} & \multicolumn{2}{|c|}{$\begin{array}{l}\text { High Neophobia } \\
\qquad(n=128)\end{array}$} & \multicolumn{2}{|c|}{$\begin{array}{l}\text { Low Neophobia } \\
\qquad(n=136)\end{array}$} & \multicolumn{2}{|c|}{$\begin{array}{l}\text { High vs. Low } \\
\text { Neophobia } \\
\text { (PLS-MGA) }\end{array}$} \\
\hline & $\begin{array}{c}\text { Path } \\
\text { Coefficients }\end{array}$ & $t$ Value & $\begin{array}{c}\text { Path } \\
\text { Coefficients }\end{array}$ & $t$ Value & $\begin{array}{c}\text { Path } \\
\text { Coefficients }\end{array}$ & $t$ Value & $\begin{array}{c}\text { Path } \\
\text { difference }\end{array}$ & $p$ Value \\
\hline $\begin{array}{c}\text { Hypothesis } 3 \mathrm{CFI} * \text { Neophobia } \\
\rightarrow \mathrm{AFI}\end{array}$ & 0.721 & $28.844^{* * *}$ & 0.785 & $28.887 * * *$ & 0.554 & $6.088 * * *$ & 0.230 & 0.001 \\
\hline $\begin{array}{c}\text { Hypothesis } 2 \mathrm{AFI} * \text { Neophobia } \\
\rightarrow \text { INT }\end{array}$ & 0.197 & $3.805^{* * *}$ & 0.331 & $2.611 * * *$ & 0.156 & 1.016 (ns) & 0.175 & 0.192 \\
\hline $\begin{array}{c}\text { Hypothesis I CFI } * \text { Neophobia } \\
\rightarrow \text { INT }\end{array}$ & 0.617 & $13.359 * * *$ & 0.460 & $4.490 *$ & 0.470 & $2.998 *$ & 0.009 & 0.532 \\
\hline
\end{tabular}

Note: $n s=$ not significant. $f^{2}$ is not provided for indirect effects. All estimates were based on a two-tailed test; for bootstrapping with a two-tailed test, a critical value of 1.96 (significant level=5\%) was chosen.

$* * * p<0.001$, *p $<0.05$.

and extreme group approach were used, splitting the overall sample $(n=500)$ into two subgroups based on the upper quartile (75th percentile) and the lower quartile (25th percentile) (Preacher et al. 2005). The groups were slightly different in size: high-neophobia group $\left(\mathrm{n}^{\text {(high) }}=128,25.6 \%\right.$, scores range $<5)$, and low-neophobia group $\left(\mathrm{n}^{(\mathrm{low})}=136\right.$, $27.2 \%$, scores range $>6.33$ ). Second, we accessed the statistical power of the groups, both of which met the minimum sample size of 52, following a statistical power of $80 \%$ required to detect minimum $R^{2}$ value of 0.25 in the INT endogenous construct at a 5\% significance level (Hair, Hult, Ringle, and Sarstedt 2017).

We then confirmed measurement invariance across the high- and low-neophobia groups. Results showed the outer loading and outer weight invariance across groups, suggesting that the neophobia construct meanings and measurements were consistent, and measurement invariance was established (Hair et al. 2018). Hence, we could proceed with examining the group differences in the structural model.

Table 10 indicates that while food neophobia has a significant and positive effect on CFI and AFI in both the high- and low-neophobia groups, the strength of the effect varies. The effect on AFI for the high-neophobia group $\left(\beta^{(\text {high })}=0.785\right.$, $p<0.05)$ was significantly stronger than that for the lowneophobia group $\left(\beta^{\text {(low) }}=0.554, p<0.05\right)$. The impact of AFI on INT was much greater in the high-neophobia group $\left(\beta^{\text {(high) }}=0.331, p<0.05\right)$ than in the low-neophobia group $\left(\beta^{\text {(low) }}=0.156, p>0.05\right)$. However, the effect of CFI on INT was similar between the high- $\left(\beta^{\text {(high) }}=0.460, p<\right.$ 0.05 ) and low-neophobia $\left(\beta^{\text {(low })}=0.470, p<0.05\right)$ groups, with both generally lower than the model based on the full sample $(\beta=0.617, p>0.05)$. The comparison of the two models showed a relatively more substantial $R^{2}$ value of intention in the high-neophobia group $\left(R^{2}=0.564\right)$ than in the low-neophobia group $\left(R^{2}=0.328\right)$, indicating the effect of cognitive and affective food image on intention was more substantial among the high-neophobia group.

According to the results of PLS-MGA, only one of three relationships - that is, between CFI and AFI - significantly varied in strength between the high- and low-neophobia groups. Therefore, the effect of perceived food image and intention was partially moderated by food neophobia, and hypothesis 4 is partially supported.

\section{Discussion and Implications}

The purpose of the present study was threefold: to validate the applicability of a destination food image model and measurement; to investigate the relationships between cognitive, affective, and conative components; and to examine the effect of food neophobia on travelers. Given the importance of food image as a driver of tourist destination choice, the model helps to identify the images formed as a set of mental representations in the minds of potential tourists, and to 
clarify their decision making and expectations in choosing Australia as a food destination. Results are useful for developing a tourist marketing strategy for Australian food and for creating distinctly different positions for Australia's desired tourist market. The findings have several theoretical and practical implications.

\section{Theoretical Contributions}

First, our proposed destination food image model is validated and can be applied in research for destination food image. The results support hypotheses 1, 2, and 3 and partially support hypothesis 4 . The findings reveal that with respect to a potential tourist's intention to visit, an individual's cognitive perceptions of distinct food and cuisine are a much stronger predictor than affective image. This finding suggests that a decision to visit a destination for its food appears to be driven largely by tourists' prior knowledge of the destination's food and cuisine. Although affective image also has a significant influence on intention to visit, its effect is not as strong as cognitive image. In contrast to our study finding, other research finds that affective image has a strong impact on satisfaction and perceived quality of food in the visit and post-visit stages (Peštek and Cinjarevic 2014). The difference in results between our study and that research may be that the two studies focused on different stages of the tour experience. This difference may suggest that the predictive power of emotion in the destination food image model - that is, the affective responses to food images - may indeed be modulated by the previsit, visit, and postvisit image-formation stages.

Although the Chinese perceived Australia's clean food environment, abundance of fresh local produce, unique food culture, and dining places with spectacular views as the most salient characteristics of Australian food tourism, these perceptions did not translate into high levels of affect and intention to visit. Possibly, during the previsit stage, prospective tourist opinions of food image are subject more to cognitive rather than affective food images, perhaps owing to an inability to preexperience the food destination and environment, especially for cuisines that are less well known or unfamiliar. In fact, Australian cuisine and restaurants are not widely available elsewhere (Financial Review 2017), unlike the cuisines of countries like France, Italy, India, Thailand, or China, which are more recognizable and widely available at a global level (Bessière 2013; Karim and Leong 2008).

Second, our study demonstrates a different methodological approach for exploratory research by using PLS-SEM to assess a hierarchical causal modeling comprising formative and reflective constructs in DI and tourist behavioral research. One of the foci is to develop a predictive model. Another focus is to maximize predictive abilities of 40 attributes of food image. Our empirical findings support the theoretical presumption of a formative measurement model for cognitive image, adding to previous argument in prior work (do Valle and Assaker 2016; Kock, Josiassen, and Assaf
2016). The study also exemplifies how a two-stage hierarchical method can be applied to examine structural relationships and to handle model complexity - that is, by clustering 40 attributes into six dimensions.

Third, the study offers a measurement of cognitive image for food destinations that captures the theoretical scope of cognitive image as a construct incorporating both host and tourist perceptions. The results extend previous food image studies by pulling together attributes valued by the destination host and those evaluated by tourists. Specifically, the place/geographic environment dimension (which had not previously been tested in tourist image studies) has been found to be one of the most critical dimensions valued and perceived as attractive by tourists. This finding indicates that future studies must consider these aspects.

Fourth, this finding extends results from previous destination food image studies by affirming that tourists' personality traits affect destination food image formation. The multigroup analysis undertaken showed partial support for hypothesis 4, that tourists' level of food neophobia moderates the relationships in the proposed DI model. Results show that people with high food neophobia are comparatively driven by emotional appeal based on their cognitive evaluation. We believe that the stronger relationships between constructs in the high-neophobia group may be explained by the low capacity to handle different or unfamiliar foods, whereas adventurous eaters tend to have a higher tolerance for exciting, novel food. These attitudes support the findings of previous research into Chinese tourists' attitudes toward consuming unfamiliar local food (Chang, Kivela, and Mak 2011; Wu et al. 2016).

\section{Practical Contributions}

Practically, this study offers insights for food destination marketing and image building. The identification of Chinese perceptions of Australian food and cuisine can assist Tourism Australia's development of a food tourism marketing strategy specifically tailored for the Chinese market. Presently, Tourism Australia tends to position Australia as a luxury food destination to drive higher international tourist spending (Lai, Khoo-Lattimore, and Wang 2018). Tourism Australia's food positioning highlights iconic and exceptional experiences such as "quality modern food and wine with fresh produce," "people with fresh thinking" (which refers to innovative chefs and a new approach to cuisine and wine-making), and its "dining places with spectacular views" (Tourism Australia 2014). Unfortunately, potential Chinese tourists did not respond to the "people" and "quality" dimensions of Tourism Australia's projected image, nor did they respond positively to the "activities" dimension. None of these dimensions could drive action to visit. On the basis of our structural modeling results, we assert that for the Chinese market, the most compelling proposition for Australian food tourism is a clean food environment producing fresh produce, a unique food culture, and dining places with 
spectacular views. This positioning requires action by Tourism Australia and its food tourism stakeholders to address these perceptual gaps.

First, the current research encourages marketers and industry practitioners to tailor persuasive campaigns for the Chinese market by strengthening the most relevant images and developing the less recognized food attributes. For instance, for the Chinese market, Australia should emphasize its clean food environment through its current campaigns of "farm to fork" and "paddock to plate." Campaign ambassadors should promote the profile of Australian agriculture and aquaculture and educate people on the origins of Australian premium produce, emphasizing producers' passion for clean and healthy meat, wholesome seafood, and garden-fresh fruits and vegetables. Some less attractive activities identified in this study have high experience appeal to Chinese travelers who have visited Australia, as suggested by the Australia consumer demand project (Tourism Australia 2016), pointing to a possible lack of awareness among potential visitors. Tourism campaigns therefore can consider bundling these underrepresented activities with high-appeal activities to enhance tourist awareness and to create unique Australian holiday experiences. For instance, images can be created to reflect activities such as visiting oyster and salmon farms and feeding the fish, visiting farms and picking fruits and vegetables, and enjoying eating experiences at farmhouse cafés or restaurants.

Second, findings indicated that people (e.g., social status, innovative chefs, friendly service staff), and food quality (e.g., price value, healthy menu, easily digestible) are not good predictors of cognitive image in the Chinese market. Although definitive reasons for these discrepancies are difficult to pinpoint, they likely result from a mismatch of images used in promoting Australian food to the Chinese market, specifically images related to high social status and price value. Indeed, visits to Australia are usually expensive for Chinese tourists owing to the high currency exchange rate (estimated AU $\$ 1=$ CNY5 in 2019). Australian food can be costly, particularly when compared to Chinese people's typical expenditure on food. Therefore, reframing the perception of perceived value is another strategy to overcome the contrasting perspectives of Australia's food image. Hence, the focus should be less on exclusive dining experiences and more on projected images of street food and food and wine festivals, which are typically associated with variety and reasonable or budget prices.

Third, while an affective image component is not as influential as cognitive image, its effect is significant. Given the power of emotions and feelings in promoting behaviors (Peštek and Cinjarevic 2014), Australia should promote this affective dimension in the earlier stage of the decision-making process to more effectively attract prospective tourists. Promotional messages should generate feelings that evoke positive emotions in target tourists. We suggest that emotional content can be tested with key tourist decision makers and opinion leaders such as individual tourists, travel agents, and journalists. Tourism Australia could invite Chinese food critics and Chinese journalists to Australia to cover and review various elements of food tourism in the country and promote Australian food tourism in the Chinese media. Conversely, Tourism Australia could organize Australian food festivals in China to showcase Australian foods and enable pre-tasting in the decision stage. These activities enable a better understanding of Australia as a food destination in the Chinese market, which should moderate the effect of unfamiliarity and create positive feelings and emotional thoughts (i.e., affective responses) before an actual visit.

Fourth, Tourism Australia can consider developing a dual strategy for tourists with high and low neophobia by educating the industry in understanding the wider variety of food offerings that Chinese tourists seek and tourists' preference for either the Eastern or Western options. The stakeholders pointed out that the mass Chinese tourist market is more neophobic than the independent travel market. As the mass market and independent market are not homogeneous in preference for, experiences with, and attitudes toward food, a dual strategy needs to be developed for each of the two markets. Findings suggest that tourists with low neophobia very much form a cognitive-driven group that values the cultural aspect of Australia's food image. To drive demand from adventurous food tourists to the destination, Australia needs a well-balanced approach to building images of its local cuisine that embed the value of cultural heritage, as well as innovative modern cuisine drawn from a vast range of cuisines from around the world. More importantly, the Australian tourism industry should compete on food attributes that the potential target market will appreciate, specifically, the authentic and exotic native foods of Australia (e.g., kangaroo, emu, and crocodile meat, lemon myrtle and wattle seeds) that are distinctive on a global level, and showcase Australia in the bestlight.

In contrast, high food neophobia groups are more emotional (driven by an affective-based image) than adventurous food groups. Therefore, Tourism Australia needs to educate the Chinese operators and ground operators in understanding how to reduce travelers' feelings of unfamiliarity and anxiety with respect to trying local foods. In fact, many Australian dishes already incorporate Asian influences. Ingredients like soy sauce, oyster sauce, and sesame oil appear in many Australian recipes. Perhaps what is needed is to incorporate the familiar with the unfamiliar by offering iconic Australian local produce with a Chinese style of cooking, like native Australian barramundi steamed with ginger and shallots, kangaroo meat stir-fried and wrapped in lettuce, or homegrown Australian wagyu beef stir-fried with rice noodles.

\section{Conclusion}

This study is not without limitations. The sample was drawn from potential tourists from China's main cities (Beijing, Shanghai, and Guangzhou), and the research was based on 
the single destination of Australia. These factors limit the generalization of results to other Chinese tourists (e.g., from Jiangsu, Zhejiang and Shandong, which are the growth markets to Australia) and other destinations. Also, as the case is contextual, future researchers need to examine the framework further to investigate cognitive food image. In addition, two attributes were not significant statistically: "Australia offers different styles of eating (e.g., eating Western food with knife and fork, and eating Chinese food with chopsticks)" and "Australia offers restaurant menus in Chinese languages." The denotation of these attributes can represent different levels of perception depending on the context of study. Furthermore, while our measure of cognitive image is comprehensive, it is subject to further extension by studies adopting a qualitative approach.

Despite its limitations, this study makes several contributions to destination food- image knowledge. First, it contributes to the literature by simultaneously examining the predictive power of cognitive and affective food image components on potential tourists in explaining their future behavioral intention. The model also integrates food image theory and food-neophobia theory to contribute a greater explanatory power to destination food image formation than earlier models, which were commonly tested solely on only cognitive or cognitive-conative components. The study also offers a comprehensive formative measurement model for cognitive food image for future research.

Second, findings on the moderating effect of food neophobia can help leverage marketers' understanding of this personality trait by distinguishing between high and low food-neophobia groups' beliefs, attitudes, and behaviors in developing gastronomic products and marketing strategies. Third, the study illustrates an impression of Australia as a food destination in the eyes of prospective Chinese tourists. The findings can potentially lead marketers to compete on food attributes that the Chinese market will appreciate and to adopt marketing strategies in line with Chinese food culture and expectations. Importantly, understanding the determinants of destination food image will inform marketing strategies and shape potential tourists' perceptions and decision-making behavior.

\section{References}

Aaker, David A. 1991. Managing Brand Equity: Capitalizing on the Value of a Brand Name. New York: Free Press.

Ab Hamid, M. R., W. Sami, and M. H. Mohmad Sidek. 2017. "Discriminant Validity Assessment: Use of Fornell \& Larcker Criterion versus HTMT Criterion." Journal of Physics: Conference Series 890:012163. doi:10.1088/17426596/890/1/012163.

Baloglu, Seyhmus, and Ken W. McCleary. 1999. "A Model of Destination Image Formation." Annals of Tourism Research 26 (4): 868-97.

Becken, Susanne, and Noel Scott. 2016. "How Australia Can Capitalise on Chinese Tourism." The Conversation. Last modified July 8, 2017. https://theconversation.com/howaustralia-can-capitalise-on-chinese-tourism-61760 (accessed Aug 8, 2017).

Bessière, Jacinthe. 2013. “'Heritagisation,' a Challenge for Tourism Promotion and Regional Development: An Example of Food Heritage." Journal of Heritage Tourism 8 (4): 275-91.

Björk, Peter, and Hannele Kauppinen-Räisänen. 2016. "Local Food: A Source for Destination Attraction." International Journal of Contemporary Hospitality Management 28 (1): 177-94.

Blichfeldt, Bodil Stilling, and Henrik Halkier. 2013. "Mussels, Tourism and Community Development: A Case Study of Place Branding through Food Festivals in Rural North Jutland, Denmark." European Planning Studies 22 (8): 1587-603.

Boniface, Priscilla. 2003. Tasting Tourism: Travelling for Food and Drink. Burlington, VT: Ashgate.

Cai, Liping A. 2002. "Cooperative Branding for Rural Destinations." Annals of Tourism Research 29 (3): 720-42.

Cenfetelli, Ronald T., and Geneviève Bassellier. 2009. "Interpretation of Formative Measurement in Information Systems Research.” MIS Quarterly 33 (4): 689-707.

Chang, Richard C. Y., Jakša Kivela, and Athena H. N. Mak. 2010. "Food Preferences of Chinese Tourists." Annals of Tourism Research 37 (4): 989-1011.

Chang, Richard C. Y., Jakša Kivela, and Athena H. N. Mak. 2011. "Attributes That Influence the Evaluation of Travel Dining Experience: When East Meets West." Tourism Management 32 (2): 307-16.

Che, Deborah. 2006. "Select Michigan: Local Food Production, Food Safety, Culinary Heritage, and Branding in Michigan Agritourism." Tourism Review International 9 (4): 349-63.

Chen, Ching-Fu, and Sambath Phou. 2013. "A Closer Look at Destination: Image, Personality, Relationship and Loyalty." Tourism Management 36:269-78.

Cohen, Erik, and Nir Avieli. 2004. "Food in Tourism: Attraction and Impediment." Annals of Tourism Research 31 (4): 755-78.

Cohen, Jacob. 1988. Statistical Power Analysis for the Behavioral Sciences, 2nd ed. Hillsdale, NJ: Lawrence Erlbaum.

Coltman, Tim, Timothy M. Devinney, David F. Midgley, and Sunil Venaik. 2008. "Formative versus Reflective Measurement Models: Two Applications of Formative Measurement." Journal of Business Research 61 (12): 1250-62.

Diamantopoulos, Adamantios, Petra Riefler, and Katharina P. Roth. 2008. "Advancing Formative Measurement Models." Journal of Business Research 61 (12): 1203-18. 
Diamantopoulos, Adamantios, and Heidi M. Winklhofer. 2001. "Index Construction with Formative Indicators: An Alternative to Scale Development." Journal of Marketing Research 38 (2): 269-77.

do Valle, Patrícia Oom, and Guy Assaker. 2016. "Using Partial Least Squares Structural Equation Modeling in Tourism Research: A Review of Past Research and Recommendations for Future Applications." Journal of Travel Research 55 (6): 695-708.

Ekinci, Yuksel, and Sameer Hosany. 2006. "Destination Personality: An Application of Brand Personality to Tourism Destinations." Journal of Travel Research 45 (2): 127-39.

Financial Review. 2017. “Australian Steakhouse Hurricane's Grill Expands in China" [News website]. The Australian Financial Review. http://www.afr.com/news/economy/trade/australiansteakhouse-hurricanes-grill-expands-in-china-20170627-gwzvqz (accessed April 4, 2017).

Fischler, Claude. 1988. "Food, Self and Identity." Social Science Information 27 (2): 275-92.

Fornell, Claes, and Fred L. Bookstein. 1982. "Two Structural Equation Models: LISREL and PLS Applied to Consumer ExitVoice Theory." Journal of Marketing Research 19 (4): 440-52.

Fornell, Claes, and David F. Larcker. 1981. "Evaluating Structural Equation Models with Unobservable Variables and Measurement Error." Journal of Marketing Research 18 (1): 39-50.

Frochot, Isabelle. 2003. "An Analysis of Regional Positioning and Its Associated Food Images in French Tourism Regional Brochures." Journal of Travel \& Tourism Marketing 14 (3/4): 77-96.

Gallarza, Martina G., Irene Gil Saura, and Haydée Calderón García. 2002. "Destination Image: Towards a Conceptual Framework." Annals of Tourism Research 29 (1): 56-78.

Gartner, William C. 1994. "Image Formation Process." Journal of Travel and Tourism Marketing 2 (2/3): 191-216.

Geisser, Seymour. 1974. "A Predictive Approach to the Random Effect Model.” Biometrika 61 (1): 101-7.

Getz, Donald, Tommy Andersson, Sanja Vujicic, and Richard N. S. Robinson. 2015. "Food Events in Lifestyle and Travel." Event Management 19 (3): 407-19.

Getz, Donald, Richard Robinson, Tommy D. Andersson, and Sanja Vujicic. 2014. Foodies and Food Tourism. Oxford: Goodfellow.

Gunn, Clare A. 1972. Vacationscape: Designing Tourist Regions, vol. 1. New York: Taylor \& Francis.

Guzman-Parra, Vanesa F., Jose Roberto Vila-Oblitas, and Javier Maqueda-Lafuente. 2016. "Exploring the Effects of Destination Image Attributes on Tourist Satisfaction and Destination Loyalty: An Application in Málaga, Spain." Tourism \& Management Studies 12 (1): 67-73.

Hair, Joseph F., G. Tomas M. Hult, Christian M. Ringle, and Marko Sarstedt. 2017. A Primer on Partial Least Squares Structural Equation Modeling (PLS-SEM), 2 vols., 2nd ed. Thousand Oaks, CA: Sage.

Hair, Joseph F., G. Tomas M. Hult, Christian M. Ringle, Marko Sarstedt, and Kai O. Thiele. 2017. "Mirror, Mirror on the Wall: A Comparative Evaluation of Composite-Based Structural Equation Modeling Methods." Journal of the Academy of Marketing Science 45 (5): 616-32.

Hair, Joseph F., Marko Sarstedt, Lucas Hopkins, and Volker G. Kuppelwieser. 2014. "Partial Least Squares Structural Equation
Modeling (PLS-SEM): An Emerging Tool in Business Research.” European Business Review 26 (2): 106-21.

Hair, Joseph F., Marko Sarstedt, Christian M. Ringle, and Siegfried P. Gudergan. 2018. Advanced Issues in Partial Least Squares Structural Equation Modeling. Thousand Oaks, CA: Sage.

Helland, Sissel H., Elling Bere, Helga Birgit Bjørnarå, and Nina Cecilie Øverby. 2017. "Food Neophobia and Its Association with Intake of Fish and Other Selected Foods in a Norwegian Sample of Toddlers: A Cross-sectional Study." Appetite 114:110-17.

Henseler, Jörg, Christian M. Ringle, and Marko Sarstedt. 2015. "A New Criterion for Assessing Discriminant Validity in Variance-Based Structural Equation Modeling." Journal of the Academy of Marketing Science 43 (1): 115-35.

Hjalager, Anne-Mette, and Magda Antonioli Corigliano. 2000. "Food for tourists - determinants of an image." International Journal of Tourism Research 2 (4): 281-93.

Huang, Songshan, Betty Weiler, and Guy Assaker. 2015. "Effects of Interpretive Guiding Outcomes on Tourist Satisfaction and Behavioral Intention." Journal of Travel Research 54 (3): 344-58.

Hunt, John Denure. 1971. "Image: A Factor in Tourism." Dissertation/Thesis, Agriculture, forest recreation, Colorado State University.

Hwang, Johye, and Ting-Ning Lin. 2010. "Effects of Food Neophobia, Familiarity, and Nutrition Information on Consumer Acceptance of Asian Menu Items." Journal of Hospitality Marketing \& Management 19 (2): 171-87.

Ji, M. J., I. A. Wong, A. Eves, and C. Scarles. 2016. "FoodRelated Personality Traits and the Moderating role of NoveltySeeking in Food Satisfaction and Travel Outcomes." Tourism Management 57:387-96.

Karim, Ab Shahrim, and Christina Geng Qing Chi. 2010. "Culinary Tourism as a Destination Attraction: An Empirical Examination of Destinations' Food Image.” Journal of Hospitality Marketing \& Management 19 (6): 531-55.

Karim, Ab Shahrim, and Jerold Leong. 2008. "Information Sources on Culinary Tourism for France, Italy and Thailand." Anatolia 19 (1): 166-71.

Keller, Kevin Lane. 1993. "Conceptualizing, Measuring, and Managing Customer-Based Brand Equity." Journal of Marketing 57 (1): 1-22.

Kim, Seongseop, Miju Kim, Jerome Agrusa, and Aejoo Lee. 2012. "Does a Food-Themed TV Drama Affect Perceptions of National Image and Intention to Visit a Country? An Empirical Study of Korea TV Drama." Journal of Travel \& Tourism Marketing 29 (4): 313-26.

Kim, Yeong Gug, Bo Won Suh, and Anita Eves. 2010. "The Relationships between Food-Related Personality Traits, Satisfaction, and Loyalty among Visitors Attending Food Events and Festivals." International Journal of Hospitality Management 29 (2): 216-26.

Kivela, Jakša, and John C. Crotts. 2006. "Tourism and Gastronomy: Gastronomy's Influence on How Tourists Experience a Destination." Journal of Hospitality \& Tourism Research 30 (3): 354-77.

Kock, Florian, Alexander Josiassen, and A. George Assaf. 2016. "Advancing Destination Image: The Destination Content Model." Annals of Tourism Research 61:28-44. 
Lai, Mun Yee, Catheryn Khoo-Lattimore, and Ying Wang. 2017. "Food and Cuisine Image in Destination Branding: Toward a Conceptual Model." Tourism and Hospitality Research 19 (2): 238-51.

Lai, Mun Yee, Catheryn Khoo-Lattimore, and Ying Wang. 2018. "A perception gap investigation into food and cuisine image attributes for destination branding from the host perspective: The case of Australia." Tourism Management 69: 579-595.

Lee, Insun, and Charles Arcodia. 2011. "The Role of Regional Food Festivals for Destination Branding." International Journal of Tourism Research 13 (4): 355-67.

Lertputtarak, Sarunya. 2012. "The Relationship between Destination Image, Food Image, and Revisiting Pattaya, Thailand." International Journal of Business and Management 7 (5): 111-22.

Lin, Yi Chin. 2009. "Linking local and culinary cuisines with destination branding." In Tourism branding: Communities in action, edited by Liping A. Cai, William C. Gartner and María Ana Munar, 105-118. Bingley, UK: Emerald Group Publishing Limited.

Lin, Yi Chin, Thomas E. Pearson, and Liping A. Cai. 2011. "Food as a Form of Destination Identity: A Tourism Destination Brand Perspective." Tourism and Hospitality Research 11 (1): $30-48$.

Long, Lucy M. 2004. Culinary Tourism. Kentucky: University Press of Kentucky.

Lowry, Paul Benjamin, and James Gaskin. 2014. "Partial Least Squares (PLS) Structural Equation Modeling (SEM) for Building and Testing Behavioral Causal Theory: When to Choose It and How to Use It." IEEE Transactions on Professional Communication 57 (2): 123-46.

Mak, Athena H. N., Margaret Lumbers, Anita Eves, and Richard C. Y. Chang. 2017. "The Effects of Food-Related Personality Traits on Tourist Food Consumption Motivations." Asia Pacific Journal of Tourism Research 22 (1): 1-20.

Martín, San Héctor, and Rodríguez Ignacio A. del Bosque. 2008. "Exploring the Cognitive-Affective Nature of Destination Image and the Role of Psychological Factors in Its Formation." Tourism Management 29 (2): 263-77.

Molinillo, S., F. Liebana-Cabanillas, R. Anaya-Sanchez, and D. Buhalis. 2018. "DMO Online Platforms: Image and Intention to Visit." Tourism Management 65:116-30.

Muhammad, Rosmaliza, Mohd Aizuddin Ibrahim, Roslina Ahmad, and Firdaus Hanan. 2016. "Psychological Factors on Food Neophobia among the Young Culinarian in Malaysia: Novel Food Preferences." Procedia-Social and Behavioral Sciences 222:358-66.

O'Brien, Robert M. 2007. "A Caution Regarding Rules of Thumb for Variance Inflation Factors." Quality \& Quantity 41 (5): 673-90.

O’Shaughnessy, John. 1992. Explaining Buyer Behavior: Central Concepts and Philosophy of Science Issues. New York: Oxford University Press.

Papadimitriou, Dimitra, Kyriaki Kaplanidou, and Artemisia Apostolopoulou. 2018. "Destination Image Components and Word-of-Mouth Intentions in Urban Tourism: A Multigroup Approach.” Journal of Hospitality \& Tourism Research 42 (4): 503-27.

Peštek, Almir, and M. Cinjarevic. 2014. "Tourist Perceived Image of Local Cuisine: The Case of Bosnian Food Culture." British Food Journal 116 (11): 1821-38.
Pike, Steven, and Chris Ryan. 2004. "Destination Positioning Analysis through a Comparison of Cognitive, Affective, and Conative Perceptions." Journal of Travel Research 42 (4): 333-42.

Pliner, Patricia, and Karen Hobden. 1992. "Development of a Scale to Measure the Trait of Food Neophobia in Humans." Appetite 19 (2): 105-20.

Prayag, Girish. 2009. “Tourists' Evaluations of Destination Image, Satisfaction, and Future Behavioral Intentions: The Case of Mauritius." Journal of Travel \& Tourism Marketing 26 (8): 836-53.

Prayag, Girish, and Chris Ryan. 2012. “Antecedents of Tourists' Loyalty to Mauritius: The Role and Influence of Destination Image, Place Attachment, Personal Involvement, and Satisfaction." Journal of Travel Research 51 (3): 342-56.

Preacher, Kristopher J., Derek D. Rucker, Robert C. MacCallum, and W. Alan Nicewander. 2005. "Use of the Extreme Groups Approach: A Critical Reexamination and New Recommendations." Psychological Methods 10 (2): 178-92.

Qu, Hailin, Lisa Hyunjung Kim, and Holly Hyunjung Im. 2011. "A Model of Destination Branding: Integrating the Concepts of the Branding and Destination Image." Tourism Management 32 (3): 465-76.

Ritchey, Phillip N., Robert A. Frank, Ulla-Kaisa Hursti, and Hely Tuorila. 2003. "Validation and Cross-National Comparison of the Food Neophobia Scale (FNS) Using Confirmatory Factor Analysis." Appetite 40 (2): 163-73.

Rozin, Paul. 1976. "Psychobiological and Cultural Determinants of Food Choice." In Dahlem Workshop on Appetite and Food Intake, edited by T. Silverstone, 285-312. Berlin: Dahlem Konferenzen.

Rozin, Paul. 1996. "Towards a Psychology of Food and Eating: From Motivation to Module to Model to Marker, Morality, Meaning, and Metaphor." Current Directions in Psychological Science 5 (1): 18-24.

Sanchez-Cañizares, Sandra, and Ana M. Castillo-Canalejo. 2015. "A Comparative Study of Tourist Attitudes towards Culinary Tourism in Spain and Slovenia." British Food Journal 117 (9): 2387-411.

Sarstedt, Marko, Joseph F. Hair, Christian M. Ringle, Kai O. Thiele, and Siegfried P. Gudergan. 2016. "Estimation Issues with PLS and CBSEM: Where the Bias Lies." Journal of Business Research 69 (10): 3998-4010.

Seo, Sunhee, and Nara Yun. 2015. "Multi-dimensional Scale to Measure Destination Food Image: Case of Korean Food." British Food Journal 117 (12): 2914-29.

Sims, Rebecca. 2009. "Food, Place and Authenticity: Local Food and the Sustainable Tourism Experience." Journal of Sustainable Tourism 17 (3): 321-36.

Smith, Stephen L. J., and Honggen Xiao. 2008. "Culinary Tourism Supply Chains: A Preliminary Examination.” Journal of Travel Research 46 (3): 289-99.

So, Kevin Kam Fung, Haemoon Oh, and Somang Min. 2018. "Motivations and Constraints of Airbnb Consumers: Findings from a Mixed-Methods Approach." Tourism Management 67:224-36.

Sparks, Beverley. 2007. "Planning a Wine Tourism Vacation? Factors That Help to Predict Tourist Behavioural Intentions.' Tourism Management 28 (5): 1180-92.

Sparks, Beverley, and Grace Wen Pan. 2009. "Chinese Outbound Tourists: Understanding Their Attitudes, Constraints and 
Use of Information Sources." Tourism Management 30 (4): 483-94.

Stone, Matthew J., Joelle Soulard, Steven Migacz, and Erik Wolf. 2017. "Elements of Memorable Food, Drink, and Culinary Tourism Experiences." Journal of Travel Research 57 (8): 1121-32.

Stone, Mervyn. 1974. "Cross-validatory Choice and Assessment of Statistical Predictions." Journal of the Royal Statistical Society 36 (2): 111-47.

Sun, Minghui, Chris Ryan, and Steve Pan. 2015. "Using Chinese Travel Blogs to Examine Perceived Destination Image: The Case of New Zealand." Journal of Travel Research 54 (4): 543-55.

Tasci, Asli D. A., and William C. Gartner. 2007. "Destination Image and Its Functional Relationships." Journal of Travel Research 45 (4): 413-25.

Tasci, Asli D. A., William C. Gartner, and Cavusgil Tamer. 2007. "Conceptualization and Operationalization of Destination Image." Journal of Hospitality \& Tourism Research 31 (2): 194-223.

Tellström, Richard, Inga Britt Gustafsson, and Lena Mossberg. 2006. "Consuming Heritage: The Use of Local Food Culture in Branding." Place Branding 2 (2): 130-43.

Tourism Australia. 2014. "Restaurant Australia: Why It's Time to Share Our Food and Wine with the World." http://www.tourism.australia.com/documents/Campaigns/TA_Austourism_ foodandwine_Factsheets.pdf (accessed June 1, 2014).

Tourism Australia. 2016. "Understanding the Chinese Market." Tourism Australia. Last modified 2016. http://www.tourism.australia.com/content/dam/assets/document/1/6/ w/u/7/2002111.pdf (accessed October 18, 2016).

Tourism Australia. 2017. "Restaurant Australia." Campaigns. http://www.australia.com/en-gb/campaigns/restaurant-australia.html (accessed January 10, 2017).

Tourism Australia. 2018. "Market Profile - China, December 2017." Tourism Australia. Last modified June 13, 2018. http://www.tourism.australia.com/en/markets-and-research/ market-regions/greater-china/china/market-profiles-usa.html (accessed June 13, 2018).

Travel Weekly. 2018. "Majority of Travellers Are Picking Destinations Based on Food." The Misfits Media Company Pty Ltd. http:// www.travelweekly.com.au/article/a-majority-of-travellers-arepicking-destinations-based-on-food/ (accessed June 28, 2018).

van Riel, Allard C. R., Jörg Henseler, Ildiko Kemeny, and Zuzana Sasovova. 2017. "Estimating Hierarchical Constructs Using Consistent Partial Least Squares: The Case of Second-Order
Composites of Common Factors." Industrial Management \& Data Systems 117 (3): 459-77.

Wang, Ying, and Michael Davidson. 2010. "Chinese Leisure Tourists: Perceptions and Satisfaction with Australia." Tourism Analysis 14 (6). doi:10.3727/108354210X12645141401106.

Williams, Helena A., Robert L. Williams Jr., and Maktoba Omar. 2014. "Gastro-Tourism as Destination Branding in Emerging Markets." International Journal of Leisure and Tourism Marketing 4 (1): 1-18.

World Tourism Organization. 2017. UNWTO Tourism Highlights: 2017 Edition. In Affiliate Members Report. Madrid, Spain: UNWTO.

Wu, Kaiyang, Carola Raab, Wen Chang, and Anjala Krishen. 2016. "Understanding Chinese Tourists' Food Consumption in the United States." Journal of Business Research 69 (10): 4706-13.

\section{Author Biographies}

Mun Yee Lai is a sessional lecturer at Griffith University, Australia. Her research interests lies in destination branding and image, food tourism, and Chinese tourist behavior. She previously worked in the hotel industry, experience in food and beverage, and catering sales. In the education industry, Mun Yee teaches in academic programs associated with tourism and hospitality, destination management, and food sociology.

Ying Wang is a senior lecturer with the Department of Tourism, Sport and Hotel Management at Griffith University (Australia) and a member of the Griffith Institute for Tourism. Her research interests include destination management and marketing, travel technologies, and hotel management. Her research work has been published in a range of international journals such as Tourism Management, Journal of Travel Research, and Annals of Tourism Research.

Catheryn Khoo-Lattimore is a senior lecturer at Griffith University, Australia. Catheryn's current research interest is on tourist and guest behavior, with a passionate focus on women, families and young children. She is also particularly interested in understanding these segments from an Asian perspective, and how their travel experience and behaviors differ cross-culturally. Catheryn is Editor-in-Chief of Tourism Management Perspectives and serves on the editorial boards of several other tourism and hospitality journals. She is Second Vice-Chair of The Council for Australasian Tourism and Hospitality Education (CAUTHE). She is also the founder and chair of Women Academics in Tourism (WAiT). 